\title{
Gonadotropin-releasing hormone and its receptor in normal and malignant cells
}

\author{
G S Harrison ${ }^{1}, M$ E Wierman ${ }^{1,2}, T M$ Nett $^{3}$ and L M Glode ${ }^{1}$
}

\author{
${ }^{1}$ University of Colorado Health Sciences, Department of Medicine, 4200 East Ninth Avenue, Denver, \\ Colorado 80262, USA \\ ${ }^{2}$ Veterans Affairs Medical Center, Denver, Colorado 80220, USA \\ ${ }^{3}$ Colorado State University, Department of Physiology, Animal Reproduction and Biotechnology Laboratory, \\ Fort Collins, Colorado 80523, USA \\ (Requests for offprints should be addressed to L M Glode; Email: mike.glode@uchsc.edu)
}

\begin{abstract}
Gonadotropin-releasing hormone $(\mathrm{GnRH})$ is the hypothalamic factor that mediates reproductive competence. Intermittent $\mathrm{GnRH}$ secretion from the hypothalamus acts upon its receptor in the anterior pituitary to regulate the production and release of the gonadotropins, $\mathrm{LH}$ and FSH. $\mathrm{LH}$ and FSH then stimulate sex steroid hormone synthesis and gametogenesis in the gonads to ensure reproductive competence. The pituitary requires pulsatile stimulation by $\mathrm{GnRH}$ to synthesize and release the gonadotropins LH and FSH. Clinically, native GnRH is used in a pump delivery system to create an episodic delivery pattern to restore hormonal defects in patients with hypogonadotropic hypogonadism. Agonists of $\mathrm{GnRH}$ are delivered in a continuous mode to turn off reproductive function by inhibiting gonadotropin production, thus lowering sex steroid production, resulting in medical castration. They have been used in endocrine disorders such as precocious puberty, endometriosis and leiomyomata, but are also studied extensively in hormone-dependent malignancies. The detection of $\mathrm{GnRH}$ and its receptor in other tissues, including the breast, ovary, endometrium, placenta and prostate suggested that $\mathrm{GnRH}$ agonists and antagonists may also have direct actions at peripheral targets. This paper reviews the current data concerning differential control of $\mathrm{GnRH}$ and $\mathrm{GnRH}$ receptor expression and signaling in the hypothalamic-pituitary axis and extrapituitary tissues. Using these data as a backdrop, we then review the literature about the action of $\mathrm{GnRH}$ in cancer cells, the utility of $\mathrm{GnRH}$ analogs in various malignancies and then update the research in novel therapies targeted to the $\mathrm{GnRH}$ receptor in cancer cells to promote anti-proliferative effects and control of tumor burden.
\end{abstract}

Endocrine-Related Cancer (2004) 11 725-748

\section{Introduction}

Gonadotropin-releasing hormone $(\mathrm{GnRH})$ is the hypothalamic factor that mediates reproductive competence (Wierman 1996, Neill 2002). Intermittent GnRH secretion from the hypothalamus acts upon its receptor in the anterior pituitary to regulate the production and release of the gonadotropins luteinizing hormone (LH) and follicle-stimulating hormone (FSH) (see Fig. 1). LH and FSH then stimulate sex steroid hormone synthesis and gametogenesis in the gonads to ensure reproductive competence. The pituitary requires pulsatile stimulation by GnRH to synthesize and release the gonadotropins LH and FSH. Continuous stimulation of pituitary GnRH receptors (GnRHR) by exogenously administered GnRH agonists, rather than pulsatile stimulation, desensitizes and down-regulates GnRHRs (Neill 2002). The ultimate effect of this chronic stimulation of the pituitary GnRHRs is to decrease LH and FSH production, with subsequent decreases in circulating sex steroid levels (Wierman 1996, Neill 2002).

Clinically, native $\mathrm{GnRH}$ is used in a pump delivery system to create an episodic delivery pattern to restore hormonal defects in patients with hypogonadotropic hypogonadism (Pitteloud et al. 2002). On the other hand, agonists of $\mathrm{GnRH}$ are delivered in a continuous mode to turn off reproductive function by inhibiting gonadotropin production (Labrie et al. 1981), thus 


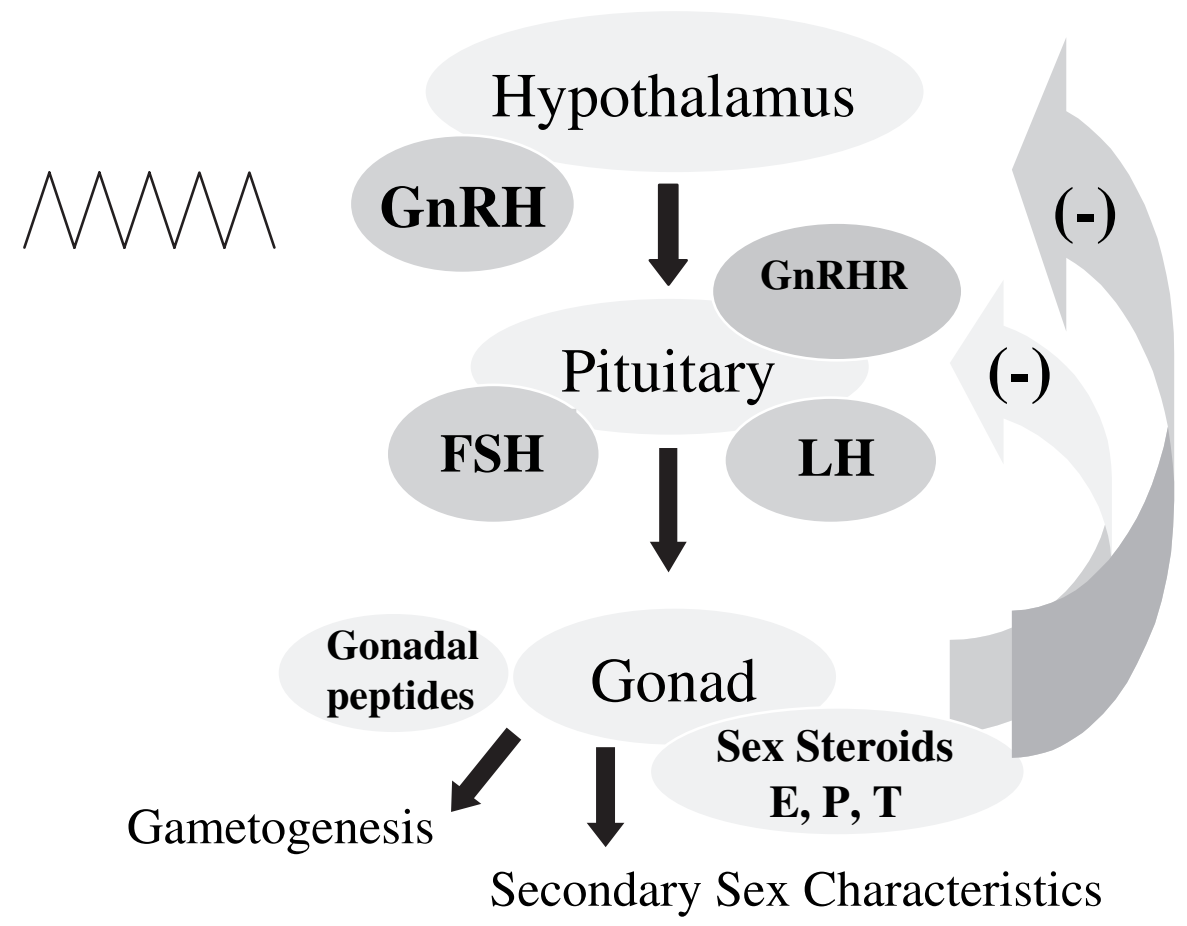

Figure 1 The hypothalamic-pituitary-gonadal axis. Secretion of GnRH from the hypothalamus occurs in a pulsatile fashion and is partially responsible for controlling the number of GnRHRs in the pituitary gland and controls synthesis and secretion of FSH and LH. These gonadotropins in turn regulate function of the testes and ovaries. $\mathrm{E}$, estrogen; $\mathrm{P}$, progesterone; $\mathrm{T}$, testosterone.

lowering sex steroid production, resulting in medical castration (Labrie 1991, Labrie et al. 1993, Huirne \& Lambalk 2001). They have been used in endocrine disorders such as precocious puberty, endometriosis and leiomyomata, but are also studied extensively in hormonedependent malignancies (Labrie et al. 1980, 1996, Huirne \& Lambalk 2001). More recently, pure GnRH antagonists have been devised to directly block GnRHRs on the pituitary and inhibit LH and FSH production (Huirne \& Lambalk 2001). Currently, they are indicated for the treatment of female infertility as adjunct therapy during ovarian hyperstimulation for in vitro fertilization and are under active investigation in various malignancies (Labrie et al. 1996, Huirne \& Lambalk 2001).

The detection of GnRH and its receptor in other tissues including the breast, ovary, endometrium, placenta and prostate suggested that GnRH agonists and antagonists may also have direct actions at peripheral targets. This paper will review the current data concerning differential control of GnRH and GnRHR expression and signaling in the hypothalamic-pituitary axis and extrapituitary tissues. Using these data as a backdrop, we will then review the literature about GnRH action in cancer cells, the utility of $\mathrm{GnRH}$ analogs in various malignancies and then update the research in novel therapies targeted to the GnRHR in cancer cells to promote anti-proliferative effects and control of tumor burden.

\section{GnRH expression and control GnRH expression profile}

At least two isoforms of GnRH have been identified in the mammalian central nervous system (CNS), GnRH-I and GnRH-II. GnRH-I is the hypothalamic decapeptide responsible for $\mathrm{LH}$ and $\mathrm{FSH}$ secretion from the anterior pituitary originally isolated by Guillemin and Schally (Guillemin 1967). GnRH-II was initially discovered as chicken GnRH-II and displays a diffuse pattern of localization in most tissues (Densmore \& Urbanski 2003, Pawson et al. 2003). In the CNS, GnRH-II has been hypothesized to play a role in the behavioral components of reproduction (Pawson et al. 2003). The genes for human GnRH-I and GnRH-II are on chromosomes 8 and 20 respectively (Wierman 1996, Limonta et al. 2003). Both isoforms of GnRH are decapeptides that are characterized by post-translational modifications, including the pyro-glutamic acid at the amino termini and amidated glycine at the carboxy termini. GnRH-I is conserved throughout evolution and has been identified in both vertebrates and invertebrates (Wierman 1996, Limonta et al. 2003). GnRH-I shares a $60 \%$ identity 
between mammals and tunicates, whereas GnRH-II is even more highly conserved with $100 \%$ identity between birds and mammals (Wierman 1996, Limonta et al. 2003). GnRH-I is synthesized as a prohormone, human preproGnRH that contains 92 amino acids. A signal peptide is contained in the first 23 amino acids, followed by the GnRH decapeptide, a 3 amino acid cleavage site and a 56 amino acid product known as GnRH-associated peptide (GAP). Post-translational processing of GnRH involves cleaving by a prohormone convertase, removal of basic amino acids by a carboxypeptidase, amino-terminus modification through the action of glutaminyl cyclase and carboxy-terminus modification by peptidylglycine $\alpha$ amidating mono-oxygenase (Wierman 1996, Limonta et al. 2003). This enzymatic processing produces mature GnRH and GAP. A physiologic role for GAP has not been determined, although it has been postulated to act as a prolactin-inhibitory factor.

\section{Control of GnRH expression}

There are approximately 1500-2000 GnRH neurons in the human (in contrast to the 800 neurons in the rodent) that are diffusely arranged in a neuronal network in the basal hypothalamus after migration (Tobet et al. 2001). The small number and dispersed population make in vivo studies of the control of GnRH expression difficult. Immortalized GnRH neuronal cell culture models as well as isolated GnRH neurons demonstrate that the GnRH 'pulse generator' is intrinsic to the neuronal cells, and have served as model systems to define the many membrane and nuclear factors important in $\mathrm{GnRH}$ expression across development (Wierman et al. 2004). During human development, the GnRH pulse generator and subsequent gonadotropin release is active in the early neonate, but decreases by 3-4 years of age (Terasawa \& Fernandez 2001, MacColl et al. 2002). Until puberty, the GnRH pulse generator is repressed. The exact mechanisms of repression are not known and may involve central $\gamma$-amino butyric acid neuronal activity (Terasawa \& Fernandez 2001). Similarly, the factors that reactivate the GnRH pulse generator during puberty are not completely understood, but the process involves activation of glutamatergic pathways (Terasawa \& Fernandez 2001).

\section{GnRHR expression and regulation}

Mammals, including humans, produce two isoforms of GnRHRs, GnRHR-I and GnRHR-II (previously called chicken GnRH-II receptor) (Clayton \& Catt 1981, Grundker et al. 2002a, McArdle et al. 2002, Kang et al. 2003, Ruf et al. 2003). Both isoforms are members of the G-protein coupled receptor (GPCR) family of proteins, couple with $\mathrm{Gq} \alpha$ and function in the inositol phosphate signaling pathway (see Fig. 2). In functional studies that measured inositol phosphate production, primate GnRHI receptors demonstrated an approximate 48-fold selectivity for GnRH-I versus GnRH-II (Gault et al. 2003, Pawson et al. 2003, Terasawa 2003). Conversely, GnRHII receptors demonstrated a 421-fold preference for GnRH-II versus GnRH-I (Gault et al. 2003, Pawson et al. 2003, Terasawa 2003). Unlike the unique GnRH-II receptor and most other GPCRs, the GnRH-I receptor contains no large cytoplasmic C-terminal tail (Clayton \& Catt 1981, Grundker et al. 2002a, McArdle et al. 2002, Kang et al. 2003, Ruf et al. 2003). The C-terminus of both types of receptors are phosphorylated in response to GnRH, leading to receptor desensitization. The GnRHRI is on chromosome 4 and the GnRHR-II is on $1 \mathrm{q}$ (Pawson et al. 2003). Although the mRNA for GnRHR-II has been cloned from monkey as well as rodent and fish species, these investigators have suggested that it is not expressed into a functional protein in the mouse or human, making the physiologic relevance of GnRHR-II in human biology a question for further study (Pawson et al. 2003).

GnRHR expression is regulated in the pituitary across sexual maturation and in response to $\mathrm{GnRH}$, sex steroids and gonadal peptides (Norwitz et al. 2002a,b, Ellsworth et al. 2003a,b, Sadie et al. 2003). Activin A augments GnRH activation of the GnRHR promoter in $\alpha \mathrm{T} 3$ pituitary cells (Norwitz et al. 2002a,b). Differential control of LH $\beta$ versus $\mathrm{FSH} \beta$ gene expression by $\mathrm{GnRH}$ is partially mediated by an up-regulation of GnRHR (Bedecarrats \& Kaiser 2003). An increase in GnRHR number in the immortalized gonadotrope cell line L $\beta$ T2 cells resulted in a disruption of the response of the FSH $\beta$ but not the LH $\beta$ promoter to GnRH (Bedecarrats \& Kaiser 2003). Together, these cell systems suggest that, at the level of the pituitary, GnRHR-I expression is tightly regulated.

\section{Signaling downstream of GnRHR in the pituitary}

\section{Effects on gonadotropin gene expression and secretion}

GnRH activation of its receptor results in stimulation of diverse signaling pathways in the anterior pituitary (Fig. 2; see Ruf et al. (2003) for detailed discussion of components of the pathway). The GnRHR is coupled to $\mathrm{Gq} / 11$ proteins to activate phospholipase $\mathrm{C}$ which transmits its signal to diacylglycerol (DAG) and inositol 1,4,5-trisphosphate (IP3) (Kraus et al. 2001, McArdle et al. 2002, Krsmanovic et al. 2003, Ruf et al. 2003). DAG activates the intracellular protein kinase $\mathrm{C}(\mathrm{PKC})$ pathway and IP3 stimulates release of intracellular calcium. In 


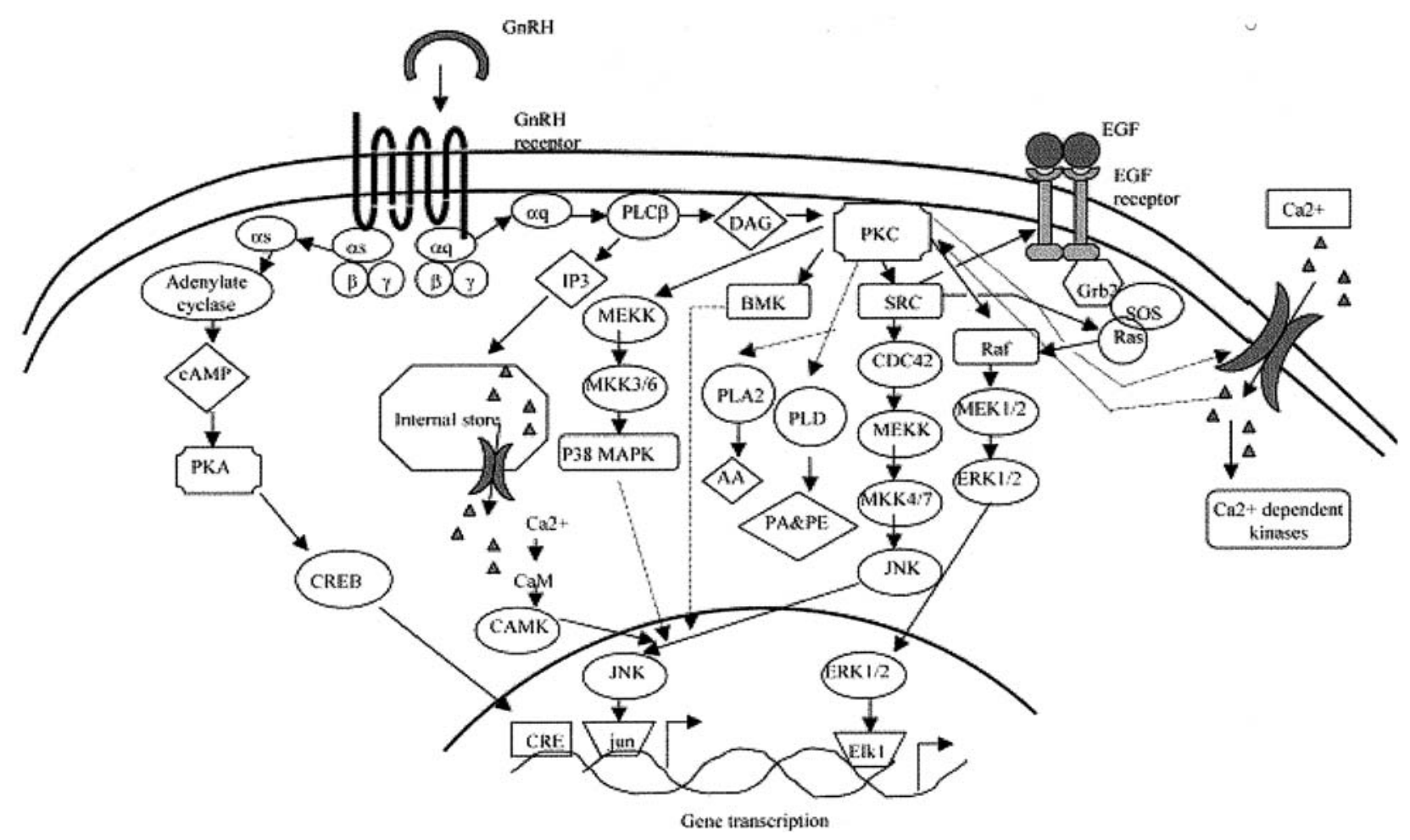

Figure 2 Effects of $\mathrm{GnRH}$ activation of its receptor in stimulating diverse signaling pathways in the anterior pituitary. (Reprinted with permission from Ruf et al. (2003)).

addition to the classical $\mathrm{Gq} / 11$, coupling of $\mathrm{Gs}$ is occasionally observed in a cell-specific fashion. PKC activation in response to $\mathrm{GnRH}$ also leads to increases in the mitogen-activated protein kinase (MAPK) pathways including ERK1,2, ERK5, p38MAPK and JNK in pituitary cells (Kraus et al. 2001, McArdle et al. 2002, Ruf et al. 2003). The active MAPKs move to the nucleus where they activate a variety of transcription factors, such as the Ets and/or AP1 families to modulate gene expression. These pathways then differentially regulate the synthesis and secretion of the gonadotropin subunits, $\alpha, \mathrm{LH} \beta$ and FSH $\beta$, in the anterior pituitary, selectively modulating gonadotropin synthesis and/or release from pituitary cells.

In L $\beta$ T2 immortalized pituitary gonadotrope cells, studies suggest the importance of $\mathrm{G}$ proteins as well as $\mathrm{Gq} / 11$ (shown to be critical in $\alpha \mathrm{T} 3$ gonadotrope cells) to regulate gonadotropin subunit gene expression (Liu et al. 2002, 2003, Vasilyev et al. 2002, Krsmanovic et al. 2003). Whether signaling downstream from the GnRHR changes across pituitary development or the differences between results in the $\alpha \mathrm{T} 3$ and $\mathrm{L} \beta \mathrm{T} 2$ are related to their immortalization by SV40 $\mathrm{T}$ antigen, remains to be determined. Desensitization in response to chronic GnRH administration in L $\beta$ T2 cells results in decreased
GnRHR and Gq/11 expression, and down-regulation of PKC, cAMP and calcium-dependent signaling (Liu et al. 2002, 2003). In addition, stimulation of ERK and p38MAPK, as well as c-Fos and LH $\beta$ protein expression, were blocked (Liu et al. 2002, 2003). These studies suggested that chronic GnRH may also result in desensitization of other Gq-coupled receptors such as the epidermal growth factor (EGF) receptor (EGFR; see Fig. 2) at the level of the pituitary (Shah et al. 2003).

\section{GnRHR cross-talk with other growth factor receptors}

In addition to the direct effects of the GnRHR in activating intracellular signaling, recent work has suggested that cross-talk with the EGFR may occur at the level of the pituitary (Shah et al. 2003). In L 3 T2 pituitary cells, Roelle et al. (2003) showed that EGFR can be activated via GnRHR based upon proteolytic release of local EGF-like ligands from transmembrane precursors. In this system, matrix metalloproteinase (MMP) 2 and 9 allow shedding of the growth factors to activate EGFR. GnRH stimulation of the cells induced Src, Ras and ERK that were dependent on the action of the MMPs, whereas activation of c-Jun N-terminal kinase and p38MAPK by 
GnRH was unaffected by the inhibition of EGFR or MMPs. GnRH activation of c-Jun and c-Fos was, however, blocked by interference with the MMPs or EGFR signaling. Together, these data underscore the complexities of direct and indirect effects of $\mathrm{GnRH} /$ GnRHR action on diverse intracellular signaling pathways.

\section{GnRHR effects on proliferation}

Recent data suggest GnRH may also modulate proliferation of gonadotropes via activation of its receptor. Miles et al. (2004) showed that continuous exposure to a GnRH signal or with the GnRH agonist leuprolide resulted in an anti-proliferative effect in L $\beta$ T2 cells. The cells accumulated in $\mathrm{G} 0 / \mathrm{G} 1$. The effects were receptor dependent in that they were blocked with the GnRH antagonist antide. Of interest, the agonist was maximally effective at nanomolar concentrations, yet little effect of native GnRH was observed until concentrations exceeded physiologic levels (Miles et al. 2004). This suggests that the mechanisms of GnRH agonist action at peripheral targets are not through normal physiologic pathways, but instead related to the potency of the agonist to bind to the receptor, the long receptor occupancy and subsequent desensitization of GnRHR, and potential cross-talk with other growth factor signaling cascades. These observations are pertinent to the possibility of direct targeting of peripheral tissues including tumors (see below).

Further support for GnRHR influence on proliferation is provided in a study by Davidson et al. (2004). They demonstrated that activation of the GnRHR results in both cell adhesion and cytoskeletal remodeling. GnRH $\left(10^{-7} \mathrm{M}\right)$ increased adhesiveness of HEK293 kidney cells overexpressing GnRHR. Cytoskeletal remodeling was dependent on focal adhesion kinase I, c-Src, ERK and Rac and independent from the classic phospholipase C signaling pathway (Davidson et al. 2004). These studies are compromised in that they utilized pharmacologic levels of GnRH which may act more like a GnRH agonist at the receptor in contrast to nanomolar concentrations normally effective in activating GnRHR downstream signaling.

\section{GnRH and GnRHR in extra-hypothalamic tissues}

In addition to the hypothalamus, GnRH-I has also been localized to the endometrium, placenta, breast, ovary, testis and prostate (Clayton \& Catt 1981, Wierman 1996, Huirne \& Lambalk 2001, Limonta et al. 2003). The exact function of GnRH-I in these tissues is under active investigation. The recent production of a transgenic mouse targeting alkaline phosphatase expression with the rat GnRHR promoter (Granger et al. 2004) and luciferase expression with the mouse GnRHR promoter (McCue et al. 1997) may provide additional model systems to identify and map developmental expression of GnRHR in extrapituitary sites. Several lines of evidence suggest that the GnRHR-I is also expressed in the brain in GnRH neurons to contribute to an ultrashort loop feedback mechanism (Xu et al. 2004).

In the endometrium and myometrium, GnRHR has been detected by radioligand binding experiments and immunohistochemistry (Clayton \& Catt 1981). In the placenta, GnRH-I and II are expressed in human placenta and are key regulators of urokinase-type plasminogen activator (uPA) and its inhibitor, plasminogen activator inhibitor (PAI-1) (Chou et al. 2003a). In endometrial stromal cultures from first trimester decidual tissues, GnRH-I and GnRH-II increased expression of uPA mRNA and protein (Chou et al. 2003a). In contrast, GnRH-I increased but GnRH-II decreased PAI-1 mRNA and protein expression. A GnRH receptor antagonist inhibited the effects of GnRH-I but not GnRH-II.

GnRH-I also increased mRNA for MMP 2 and 9 in decidual stromal cultures with no effect on tissue inhibitors of metalloproteinases (TIMP)-1 (Chou et al. $2003 b$ ). In the placenta, GnRH-I and GnRH-II increased the production of MMPs and decreased the expression of TIMPs in trophoblasts. The effects of GnRH-I but not GnRH-II were blocked by a GnRH antagonist (Chou et al. 2003c). These results suggest the complex interaction of GnRH action both in the endometrium and placenta impacting on implantation. The studies also support the hypothesis that a functional GnRH-II may not be expressed in humans, explaining the divergent results with GnRH-II versus GnRH-I. Together, these data suggest that, in the endometrium and placenta, the effects of native GnRH and GnRH agonists may be similar. The down-regulation of GnRHR that occurs at the level of the pituitary in response to tonic stimulation by $\mathrm{GnRH}$ may not occur in these peripheral sites. Further studies are needed to clarify the control of $\mathrm{GnRH}$ and its receptor in these tissues.

In the ovary, in situ studies have shown the presence of the GnRH-I mRNA in granulosa cells of primary, secondary and tertiary follicles (Kang et al. 2003). Recently, investigators have shown the presence of GnRH-II in human granulosa-luteal cells (hGLCs), immortalized ovarian surface epithelial (OSE) cells and in ovarian cancer cells (Kang et al. 2003). Some studies suggest a physiologic role of the GnRH system in the control of atresia (Kang et al. 2003). GnRH can inhibit DNA synthesis, induce apoptosis and activate genes important for follicular rupture and oocyte maturation 
such as plasminogen activator, prostaglandin endoperoxide synthase type 2 and progesterone receptor, and those important for matrix remodeling such as the MMPs (Kang et al. 2003).

GnRHR expression changes in the ovary correlate with the degree of follicular development across the estrous cycle (Kang et al. 2003). GnRH-I induced a biphasic effect on GnRH and GnRHR expression in hGLCs and OSE cells. Estrogen treatment resulted in an initial up- and then down-regulation of GnRH and GnRHR expression. GnRH agonist administration can also down-regulate estrogen receptors $\alpha$ and $\beta$ in ovarian cells (Kang et al. 2003). Recent work has suggested that the GnRHR promoter is controlled by a unique upstream regulatory sequence in human ovarian granulosa-luteal cells which was not critical in ovarian cancer cells or pituitary cells (Cheng et al. 2002). Thus, there may be tissue-specific regulation of GnRH/GnRHR pathways.

In the breast, both GnRH and GnRHR have been detected by RT-PCR (Kottler et al. 1997). Most studies involved testing of breast cancer cell lines in the absence of normal breast samples (Kakar et al. 1994). GnRH agonists inhibit malignant breast epithelial cells (Kakar et al. 1994). In the absence of studies on normal human breast tissue or normal breast cell lines, the direct action of GnRH via its receptor in the breast in the absence of malignancy remains to be elucidated.

In the testes, GnRH mRNA is expressed in Sertoli cells while the GnRHR is expressed in the Leydig cells by RTPCR (Bahk et al. 1995, Botte et al. 1998). In early fetal development in the rat, GnRH mRNA expression in the testis precedes that in the ovary, followed by GnRHR expression. In late fetal development, levels of $\mathrm{GnRH}$ and its receptor increased first in females in the ovary and then in males in the testes (Dufau et al. 1984, Botte et al. 1999). In cultured testes, GnRH increased GnRHR, and GnRH agonists blocked steroidogenesis, supporting a direct action of GnRH in the testis (Dufau et al. 1984, Botte et al. 1999). These effects of GnRH or GnRH agonists may not be physiologic. No studies are available concerning the regulation of GnRH or GnRHR in the human testis.

In the prostate, GnRHR has been detected in human samples of benign prostatic hypertrophy (BPH) (Bono et al. 2002). GnRHR has been detected by RT-PCR in prostate biopsies with levels lower in normal prostate than in prostate cancer specimens (Bono et al. 2002). No normal human prostate cell lines exist to clarify the role of GnRH signaling in normal prostate.

In summary, GnRH and GnRHR are expressed in many peripheral tissues. The functional physiologic role of the ligand and its receptor in these sites is under active investigation. Problems with the current literature include the detection of GnRH and GnRHR mRNA often with
RT-PCR techniques without functional assays of protein expression and ligand-binding assays. Studies of potential physiologic signaling via GnRHR in extrapituitary tissues are flawed by the sole use of GnRH agonists and/or antagonists with long half-lives, often at pharmacologic levels. These agents may trigger signaling via local GnRHR that is different from potential physiologic paracrine signaling from local GnRH/GnRHR activity. Cell systems serve as models for GnRHR signaling. However, many are not physiologic models. This may explain the divergent pathways detected and confuse the complexities of functional pathways in vivo. Finally, few cutting-edge techniques have been used to date to prove that the effects of GnRH agonists or antagonists in peripheral target tissues are via the GnRHR, such as the use of siRNA, antisense technology or tissue-specific knockouts. Further research is needed to differentiate between GnRH/GnRHR signaling in normal pituitary and extrapituitary sites and show how it differs from that observed in cancer cells.

\section{Aberrant expression of GnRHR in cancer}

Various disease and/or transformed epithelial cells are known to express the GnRHR (Friess et al. 1991, Kakar \& Jennes 1995, Chatzaki et al. 1996, Kottler et al. 1997, Barbieri 1998, Yin et al. 1998, Ortmann \& Diedrich 1999, Borroni et al. 2000, Halmos et al. 2000, Kang et al. 2000, Lee et al. 2000, Noci et al. 2000), and the GnRHRs present on hormonally responsive tumor cells appear to be identical to the high-affinity pituitary receptor. Recently, GnRHR-II, which transmits significantly stronger anti-proliferative effects than GnRHR-I, has been identified in ovarian and endometrial cancers (Kang et al. 2000, Bedecarrats \& Kaiser 2003); the significance of this remains to be determined as the role of GnRH-II has not been elucidated.

Cancer types with cells expressing the GnRHR include breast, prostate, endometrial cells in endometriosis and endometrial cancer, ovarian, pancreatic and hepatoma (reviewed by Imai \& Tamaya 2000). Analysis shows that the GnRHR-I sequences in these cancer cell types are identical to those in pituitary gonadotropes (Chatzaki et al. 1996, Yin et al. 1998), and binding studies have demonstrated the functionality of these receptors. High-affinity and low-affinity GnRH-binding sites have been found in $90 \%$ and $50 \%$ of ovarian cancer biopsies respectively (Emons et al. 1993, Emons \& Schally 1994, Imai \& Tamaya 2000). While ovarian cancer is not hormone responsive, the presence of GnRH-binding sites, as well as the intraperitoneal distribution of the tumor, makes this disease an especially attractive model for GnRH-toxin therapy. 
About $80 \%$ of endometrial cancers and $50 \%$ of breast cancers express both GnRH and GnRHR as part of an autocrine system (Emons et al. 2003). Similarly, it has been reported that $86 \%$ of human prostate adenocarcinomas express high-affinity binding sites for GnRH and express mRNA for the receptor; higher Gleason score tumors show reduced receptor numbers, but higher affinity receptors (Halmos et al. 2000). Proliferation of ovarian cancer cells was shown to increase after treatment with an antiserum to GnRH, supporting the idea that GnRH produced by the tumor cells acts as a negative autocrine regulator (Emons et al. 2000). Native GnRH, as well as GnRH agonists and antagonists, inhibited proliferation of cancer cells in a dose- and time-dependent manner (reviewed by Grundker et al. 2002b).

The anti-proliferative effect of GnRH analogs is mediated, at least in part, by changes in signal transduction (recently reviewed by Emons et al. 2003, Limonta et al. 2003). When bound to its ligand in cancer cells, the GnRHR couples to $\mathrm{G}$ protein $\alpha \mathrm{i}$, activating a phosphotyrosine phosphatase which dephosphorylates EGFRs (Grundker et al. 2001). This in turn suppresses EGFinduced activation of MAPK and c-fos, thus inhibiting proliferation (Emons et al. 1996, Grundker et al. 2000a). This mechanism of cell signaling in cancer cells is different from that observed in pituitary cells, as described in the section on 'Effects on gonadotropin gene expression and secretion'. There are also data supporting the role of GnRH-I in apoptosis in tumor cells, but this remains controversial (Grundker et al. 2000b, Wang et al. 2002).

Fewer GnRH-binding sites have been found in sex steroid-independent gynecologic tumors such as cervical carcinoma (Imai et al. 1994). Using RT-PCR to detect message, there was significantly lower expression of the receptor in $\mathrm{BPH}$ and normal prostate tissues (Straub et al. 2001). However, GnRH-I behaves as a negative regulator of growth in some tumors outside of the reproductive tract such as melanoma (Limonta et al. 2003). In these cancer cells, the biochemical and pharmacological profiles of GnRHR-I correspond to those in pituitary cells (Limonta et al. 2003). GnRH-I-binding sites have also been described in glioblastoma (van Groeninghen et al. 1998) and in leukemic T cells (Chen et al. 2002).

\section{Current use of GnRH analogs in cancer}

With the elucidation of the structure of GnRH-I by Guillemin and Schally (Guillemin 1967), it became possible to synthesize thousands of different analogs of the primary decapeptide. Although agonists were recognized early on (Labrie et al. 1980, 1981, Faure et al. 1982) and have been employed in clinical medicine for more than 25 years, they act as delayed inhibitors of LH and FSH secretion following the initial agonistic activity. The mechanisms underlying this desensitization simulate continuous infusions of GnRH which down-regulate GnRHR and Gq/11 expression resulting in decreased PKC-, cAMP- and Cadependent signaling, possibly resulting in decreased bioactive and immunoreactive gonadotropin secretion (Labrie et al. 1996, Labrie 2004). The development of safe and effective GnRH antagonists required considerably longer, necessitating the substitution of three or more amino acids to achieve the desired pharmacologic profiles (van Loenen et al. 2002) (Table 1).

\section{GnRH analogs in prostate cancer}

Phase I trials in men with clinical stage D prostate cancer with the agonist leuprolide acetate demonstrated that doses of 1-10 mg daily effectively reduced testosterone to the castrate range (Warner et al. 1983). A small phase III trial was then completed in similar stage D metastatic prostate cancer patients in which the efficacy of leuprolide, administered as a single daily $1 \mathrm{mg}$ injection, was compared with a single oral $3 \mathrm{mg}$ dose of diethylstilbestrol (DES). Comparable numbers of patients in both groups had suppression of testosterone, dihydrotestosterone and the only tumor marker available at that time, acid phosphatase. Tumor responses were equivalent, but the DES side-effects of gynecomastia, nausea/vomiting and thromboembolism led to the Federal Drug Administration (FDA) approval of leuprolide as a safer means of achieving medical castration (Anonymous 1984). Although orchiectomy remains a safe, effective alternative, it is often rejected by patients because of the psychologic side-effects (Samdal et al. 1991). The excess costs (compared with surgical castration) of these psychologic decisions by individual patients are estimated to be approximately \$386/month (Chon et al. 2000), while the overall costs to the USA Medicare healthcare system are about $\$ 1.2$ billion dollars annually for the two available GnRH agonists, leuprolide and goserelin (Anonymous 2003).

Treatment with GnRH agonists results in transient elevations in testosterone and dihydrotestosterone. In a fraction of patients with metastatic disease, this can result in 'tumor flare' characterized by worsening of disease symptoms. These include worsening of bone pain, urethral or ureteral obstruction and, of gravest concern, spinal cord compression or even death in patients with advanced metastatic disease. These effects can be blocked (Labrie et al. 1984, 1987, Kuhn et al. 1989) with the shortterm administration of an anti-androgen.

A much more controversial issue is the longer term use of either steroidal (flutamide, bicalutamide or nilutamide) or non-steroidal (megestrol or cyproterone) anti-androgens in combination with the GnRH agonists 
Table $1 \mathrm{GnRH}$ agonists and antagonists. Reprinted with permission from van Loenen et al. 2000.

\begin{tabular}{|c|c|c|c|c|c|c|c|c|c|c|}
\hline \multirow[b]{2}{*}{ Name } & \multicolumn{10}{|c|}{ Amino acid sequence } \\
\hline & $\begin{array}{l}1 \\
\text { pGlu }\end{array}$ & $\begin{array}{l}2 \\
\text { His }\end{array}$ & $\begin{array}{l}3 \\
\text { Trp }\end{array}$ & $\begin{array}{l}4 \\
\text { Ser }\end{array}$ & $\begin{array}{l}5 \\
\text { Tyr }\end{array}$ & $\begin{array}{l}6 \\
\text { Gly }\end{array}$ & $\begin{array}{l}7 \\
\text { Leu }\end{array}$ & $\begin{array}{l}8 \\
\text { Arg }\end{array}$ & $\begin{array}{l}9 \\
\text { Pro }\end{array}$ & $\begin{array}{l}10 \\
\text { Gly-NH}{ }_{2}\end{array}$ \\
\hline \multicolumn{11}{|l|}{ Human GnRH } \\
\hline GnRH-I & 1 & 2 & 3 & 4 & 5 & 6 & 7 & 8 & 9 & 10 \\
\hline GnRH-II & 1 & 2 & 3 & 4 & His & 6 & Trp & Tyr & 9 & 10 \\
\hline GnRH-IIII & 1 & 2 & 3 & 4 & 5 & 6 & Trp & Leu & 9 & 10 \\
\hline \multicolumn{11}{|l|}{ GnRH agonist } \\
\hline \multicolumn{11}{|l|}{ Nonapeptides } \\
\hline Leuprorelin & 1 & 2 & 3 & 4 & 5 & D-Leu & 7 & 8 & $9-$ & $\mathrm{N}-\mathrm{Et}-\mathrm{NH}_{2}$ \\
\hline Buserelin & 1 & 2 & 3 & 4 & 5 & $\mathrm{D}-\mathrm{SER}\left(\mathrm{Bu}^{1}\right)$ & 7 & 8 & $9-$ & $\mathrm{N}-\mathrm{Et}-\mathrm{NH}_{2}$ \\
\hline Goserelin & 1 & 2 & 3 & 4 & 5 & $\mathrm{D}-\mathrm{SER}\left(\mathrm{Bu}^{1}\right)$ & 7 & 8 & $9-$ & AzaGly- $\mathrm{NH}_{2}$ \\
\hline Histrelin & 1 & 2 & 3 & 4 & 5 & D-His(Imbzl) & 7 & 8 & $9-$ & $\mathrm{N}-\mathrm{Et}-\mathrm{NH}_{2}$ \\
\hline Deslorelin & 1 & 2 & 3 & 4 & 5 & D-Trp & 7 & 8 & $9-$ & $\mathrm{N}-\mathrm{Et}-\mathrm{NH}_{2}$ \\
\hline \multicolumn{11}{|l|}{ Decapeptides } \\
\hline Nafarelin & 1 & 2 & 3 & 4 & 5 & $(\mathrm{~d}-\mathrm{Nal})_{2}$ & 7 & 8 & 9 & Gly-NH${ }_{2}$ \\
\hline Triptorelin & 1 & 2 & 3 & 4 & 5 & D-Trp & 7 & 8 & 9 & Gly-NH ${ }_{2}$ \\
\hline \multicolumn{11}{|l|}{ GnRH antagonist } \\
\hline Abarelix & D-Ala & D-Phe & D-Ala & 4 & 5 & D-Asp & 7 & Lys(iPr) & 9 & D-Ala \\
\hline Antarelix & D-Nal & D-Phe & D-Pal & 4 & Phe & D-Hcit & 7 & Lys(iPr) & 9 & D-Ala \\
\hline Cetrorelix & D-Nal & D-Phe & D-Pal & 4 & 5 & D-Cit & 7 & 8 & 9 & D-Ala \\
\hline Ganirelix & D-Nal & D-Phe & D-Pal & 4 & 5 & D-hArg & 7 & HArg & 9 & D-Ala \\
\hline Iturelix (Antide) & D-Nal & D-Phe & D-Pal & 4 & NicLys & D-NicLys & 7 & Lys(iPr) & 9 & D-Ala \\
\hline Nal-Glu & D-Nal & D-Phe & D-Pal & 4 & D-Glu & D-Glu & 7 & 8 & 9 & D-Ala \\
\hline
\end{tabular}

in the treatment of prostate cancer. While these agents can prevent some of the physiologic effects of the androgeninduced tumor flare, they also have the theoretic advantage of blocking adrenal androgens. In addition, they would be expected to enhance tumor control in the occasional patient who experiences 'escape' from chronic GnRH agonist administration. A thorough meta-analysis of 8275 men who participated in 27 randomized trials of medical/surgical castration with or without the addition of anti-androgen therapy concluded that the addition of anti-androgens improved the 5-year survival by only 2 or $3 \%$ (Anonymous 2000). As there is some variability in the definition of 'castrate levels' of testosterone (traditionally $<50 \mathrm{ng} / \mathrm{dl}$ ) and the fact that men who are surgically castrated rarely have total testosterone levels exceeding $20 \mathrm{ng} / \mathrm{dl}$, the National Comprehensive Cancer Network has recommended using the latter level as a lower threshold (Millikan \& Logothetics 1997). A more recent review (Loblaw et al. 2004) of hormonal management for androgen-sensitive prostate cancer concludes that 'Combined androgen blockade confers a statistically significant but questionable clinical improvement in survival over orchiectomy or LHRH monotherapy' and that '.... treatment with antiandrogen monotherapy appears unlikely to lead to a survival benefit in men with localized disease managed with non-definitive therapy (watchful waiting)'. As this active debate on the effects of steroidal versus nonsteroidal anti-androgens is beyond the scope of this review article, the reader is referred to Loblaw et al. (2004) for current guidelines and recommendations.

The first GnRH antagonist to be approved for clinical use in the USA was abarelix (Table 1). A randomized phase III multicenter study comparing its efficacy with the combination of leuprolide and bicalutamide revealed that over half of abarelix-treated patients achieved castrate $(<50 \mathrm{ng} / \mathrm{dl})$ levels of testosterone by day 4 while $79 \%$ of the combination-treated patients had still not achieved castrate levels by day 15 (Trachtenberg et al. 2002) (Fig. $3)$. Although the rate of fall in prostate specific antigen (PSA) levels among the two groups was similar, the potential avoidance of tumor flare via the use of abarelix in patients with impending cord or ureteral/urethral urinary tract obstruction or severe bone pain persisting on narcotic analgesics led to FDA approval for use in these limited circumstances. Unfortunately, the clinical trials leading to this approval also revealed a low incidence of immediate-onset allergic reactions that included hypotension and syncope. These phenomena led to a black box warning that patients who are administered abarelix need to be observed in the physician's office for $30 \mathrm{~min}$ following each administration and physicians must participate in a training program to ensure their competence to manage these side-effects. Nevertheless, abarelix offers an important alternative to surgical castration, the use of ketoconazole or GnRH agonist plus anti-androgen in the patient who presents 


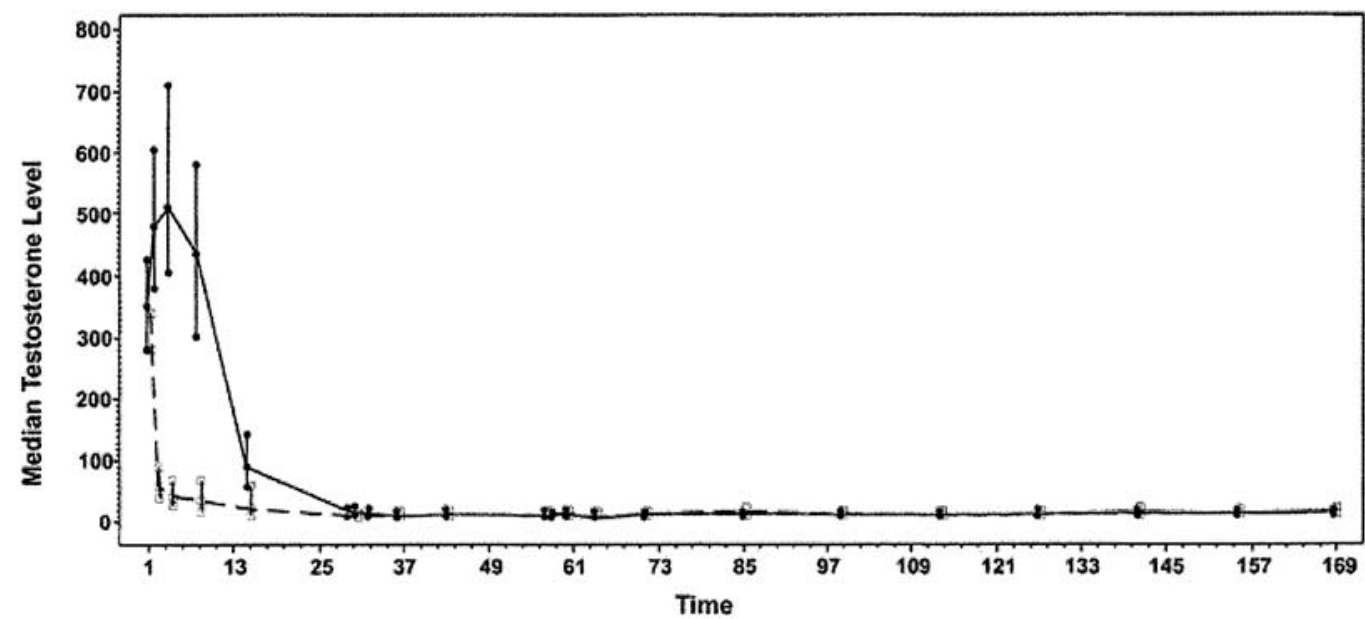

Figure 3 Median ( \pm S.E.M.) serum testosterone level in patients treated with abarelix depot (broken line) and those treated with leuprolide acetate and bicalutamide (solid line) on study days 1 through 169. (Reprinted with permission from Trachtenberg et al. (2002)).

with significant neurologic or urinary obstructive symptoms.

The duration of response and survival of patients treated with GnRH analogs or other means of androgen deprivation therapy (ADT) depends largely on their clinical status and volume of disease. Table 2 lists some of the important factors that have been found to influence responses (Oefelein \& Resnick 2003). The timing of GnRH agonist ADT (i.e. when to initiate therapy and for how long to continue it) has generated considerable discussion and a variety of experimental approaches simply because, unlike surgical castration, GnRH agonist therapy is reversible.

With the advent of PSA testing, it has become possible to detect residual, advancing disease months to years before any symptoms develop. One of the few studies on the natural history of patients who go untreated after a PSA rise is detected after successful prostatectomy revealed that radionuclide scans and other body imaging studies do not detect metastases for a median of 8 years from the time of biochemical progression (Pound et al. 1999). Predictors of more rapid development of clinical metastases are the initial Gleason score, the time-interval between prostatectomy and initial PSA detection and the doubling time of the PSA once detectable. In this study, the median time from radiographic metastases to death was 5 years. These data suggest that men can wait until radiographic progression is detected before initiation of ADT. Early treatment of prostate cancer is reviewed by Labrie et al. (2002).

Against this approach are studies showing that early use of GnRH agonist or other ADT for prostate cancer

Table 2 Clinical factors predictive of response and overall survival in patients with prostate cancer treated with androgen suppression therapy. Reprinted with permission from Oefelein \& Resnick 2003.

\begin{tabular}{lll}
\hline Variable & Good prognostic factors & Reference \\
\hline Nadir PSA & Undectable & Oefelein et al. 2002 \\
Time to nadir PSA & $<3$ months & Oefelein et al. 2002 \\
Baseline PSA & Low & Sabbatini et al. 1999 \\
$\begin{array}{l}\text { Tumor grade } \\
\text { Bone pain }\end{array}$ & Low & Albertsen et al. 1995 \\
Extent of metastases & No pain & de Voogt et al. 1989 \\
& Minimal & Sabbatini et al. 1999 \\
Performance status & & de Voogt et al. 1989, \\
& Low & Sabbatini et al. 1999 \\
Alkaline phosphatase & & de Voogt et al. 1989, \\
Tumor stage & Low & Sabbatini et al. 1999 \\
Hemoglobin & Low & de Voogt et al. 1989 \\
Body mass index & High & Sabbatini et al. 1999 \\
Pretreatment testosterone & Low & Oefelein et al. 2002 \\
& Low & Chodak et al. 1991
\end{tabular}




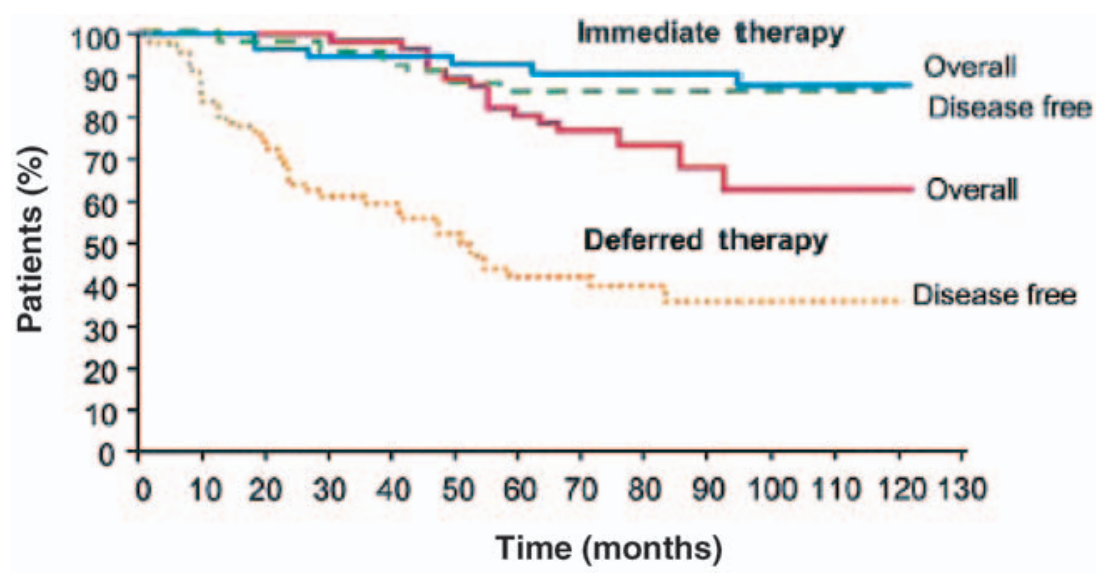

Figure 4 Eastern Cooperative Oncology Group: disease-free and overall survival data. Kaplan-Meier estimates of overall survival and disease-free survival in patients receiving immediate versus deferred hormonal therapy. (From Crawford (2003), adapted with permission from Messing et al. (1999)).

can improve overall survival. When combined with radiation therapy for advanced local disease, two large randomized trials showed either disease-free or overall survival advantages compared with radiation alone (Pilepich et al. 1995, Bolla et al. 1997). Similarly, in patients with nodal metastases at the time of prostatectomy, immediate medical or surgical castration improved the 5-year survival when compared with waiting until metastases (or rising PSA) were evident (Messing et al. 1999) (Fig. 4).

However, the GnRH agonists produce considerable side-effects including hot flashes, accelerated bone resorption, impotence, loss of libido, loss of muscle mass and, in some instances, profound psychologic effects. One approach to avoid these toxicities would be better selection of patients for early hormonal ablation. Various algorithms and neural networks have been developed to try to better predict which patients would benefit the most from early ADT (Crawford 2003). Further pharmacologic intervention can be used as well, adding additional drugs (and expense) to the patient's treatment regimen. For example, calcium and vitamin D supplementation with or without bisphosphonates can significantly reduce bone loss (Smith 2003). Hot flashes can be ameliorated in approximately half of the patients by prescribing venlafaxine (Quella et al. 1999), estrogens or progestins. A variety of partially effective measures can be tried to alleviate sexual dysfunction (Higano 2003).

Since the GnRH analogs are reversible, another less well-studied approach to their use is intermittent therapy. Prostate cancer cells deprived of androgen stimulation eventually become androgen independent, leading to clinical progression of metastases. Resistance to combined androgen blockade in localized disease is not yet understood; its occurrence in metastatic disease is discussed by
Labrie et al. (2002). The molecular events accompanying this phenomenon include mutations in or overexpression of the androgen receptor and alterations in other signaling pathways that lead to loss of the capacity for the cells to undergo apoptosis (Avila et al. 2001). In theory, allowing patients to recover from GnRH analog-induced ADT could delay or prevent the emergence of such cells, and prolong the duration of the hormone-sensitive state. Early experiments with this approach in animals demonstrated a 3-fold prolongation of the hormone-sensitive state (Sato et al. 1996). These observations led to a phase II clinical trial that found improved quality of life in men treated with intermittent ADT without obvious compromise in duration of responsiveness or survival (Goldenberg et al. 1999). Although the quality of life in intermittently treated patients is improved, the overall impact on survival and duration of hormone responsiveness is unknown. Two large randomized trials in the USA and Canada are being performed to answer these questions (Pether et al. 2003).

\section{GnRH analogs in breast cancer}

It was first recognized that surgical ovarian ablation could produce clinical responses in breast cancer in the late $19^{\text {th }}$ century by Albert Schinzinger and, later, George Thomas Beatson (Love \& Philips 2002). Additional endocrine ablative options including adrenalectomy, hypophysectomy and radiation ablation of the ovaries all received attention in the $20^{\text {th }}$ century, but all are irreversible and invasive. Response rates to oophorectomy in premenopausal metastatic breast cancer patients vary from 30 to $75 \%$ with the highest responses in patients with estrogen receptor (ER)- and/or progesterone receptor (PR)-positive tumors (Sunderland \& Osborne 1991). As with 
prostate cancer, gonadal ablation with a GnRH analog was shown to be equivalent to surgical oophorectomy in premenopausal patients with receptor-positive disease although, surprisingly, there was an approximate 15 -year delay in such trials, possibly due to the availability of effective anti-estrogens like tamoxifen (Taylor et al. 1998).

With the advent of adjuvant chemotherapy, it was widely recognized that at least some of the benefit of treatment was due to chemically induced menopause. Multiple studies did not resolve the controversy over which effect was more important, the cytotoxic effect of chemotherapy agents on the cancer cells, which could extend to the ER/PR-negative populations, or the chemotherapy-induced ovarian failure (Pritchard 2002). The value of permanent ovarian ablation by surgery or radiotherapy in premenopausal women under 50 years of age with both node-positive and node-negative disease was established by several randomized trials performed by the Early Breast Cancer Trialists' Collaborative Group (Anonymous 1996). More recently, this group reported on a randomized trial of adjuvant chemotherapy followed by goserelin versus either modality alone in premenopausal node-negative patients. The study accrued 1063 patients from 1990 to 1999 and stratified participants according to ER status. ER-negative patients fared best if they received chemotherapy with some additional improvement by the GnRH agonist treatment. In contrast, ER-positive patients had similar outcomes regardless of the treatment arm, suggesting equivalence of the therapies. A possible exception was noted for those women under 39 years of age where the combination of chemotherapy followed by goserelin resulted in superior disease-free survival (Castiglione-Gertsch et al. 2003). There are many nuances in considering these outcomes, such as reserving the addition of a GnRH agonist only for those patients who are not rendered menopausal by the chemotherapy and the sideeffects of chemotherapy versus those of ovarian ablation. Further, newer regimens of chemotherapy which are superior to the 'classic CMF' (cytoxan, methotrexate, 5fluorouracil) regimen used in this study complicate the interpretation of results such that some experts feel ovarian ablation should not be recommended routinely to premenopausal patients otherwise being treated with newer regimens (Pater \& Parulekar 2003).

For premenopausal node-positive patients similar findings hold for adjuvant therapy. A large randomized study sponsored by the manufacturer of goserelin compared treatment with 'classic CMF' versus goserelin, accruing approximately 800 patients in each group between 1990 and 1996. The disease-free survival was equivalent in those patients $(\sim 60 \%)$ with ER-positive disease, while those with ER-negative tumors again fared best with chemotherapy. The quality of life was superior in the goserelin-treated group (de Haes et al. 2003). This study did not include a group treated with both modalities, but did document amenorrhea rates which were approximately $65 \%$ during the first 6 months of chemotherapy. Again, the practicing clinician must weigh these findings in the light of superior chemotherapy regimens compared with the CMF regimen employed in the trial (Jonat et al. 2002).

Premenopausal patients with metastatic disease have often been treated with the anti-estrogen tamoxifen because of numerous studies showing equivalence with ovarian ablation (Crump et al. 1997). As tamoxifen is relatively inexpensive, easily administered and comparatively well tolerated, there have been few studies comparing its use with the GnRH agonists alone or in combination with tamoxifen. A meta-analysis of four small studies suggested there might be a benefit from the combination, but no large trials have been performed (Boccardo et al. 1999, Pritchard 2000). Most attention in this area as well as in the treatment of postmenopausal patients is now directed at the use of third generation aromatase inhibitors (Buzdar 2004).

\section{Clinical studies with targeted toxins}

The approach of coupling cytotoxic agents to $\mathrm{GnRH}$ has been used in model systems to test therapies for a number of tumors possessing GnRHRs (see section on 'Aberrant expression of GnRHR in cancer'). To achieve specificity in a GnRH-toxin approach, the GnRHR levels on cell types other than the targeted tumor must be considerably lower than on the tumor cells.

In animal studies, passive immunization was achieved with anti-GnRH antibodies in nude mice with human breast cancer cell xenografts (Jacobs et al. 1999). GnRHPseudomonas exotoxin (PE) conjugates were also shown to reduce adenocarcinoma tumor size when injected in a nude mouse xenograft model (Ben-Yehudah et al. 1999). In a human clinical study (Simms et al. 2000), GnRH decapeptide conjugated to diphtheria toxoid was injected into patients with locally advanced prostate cancer. In all patients, antibodies to GnRH and castrate levels of testosterone (which appeared to be reversible) were produced. In short, the presence of elevated levels of functional GnRHR in certain tumor types supports the notion that the GnRHR is a good candidate for targeted therapies.

Many chemotherapeutic agents used to treat cancer require interaction with DNA, transcriptional machinery or microtubules to disrupt cellular function. Therefore, potentially thousands of molecules may have to be delivered to a cell to inhibit its function completely. In the past two decades a novel approach, the use of targeted 


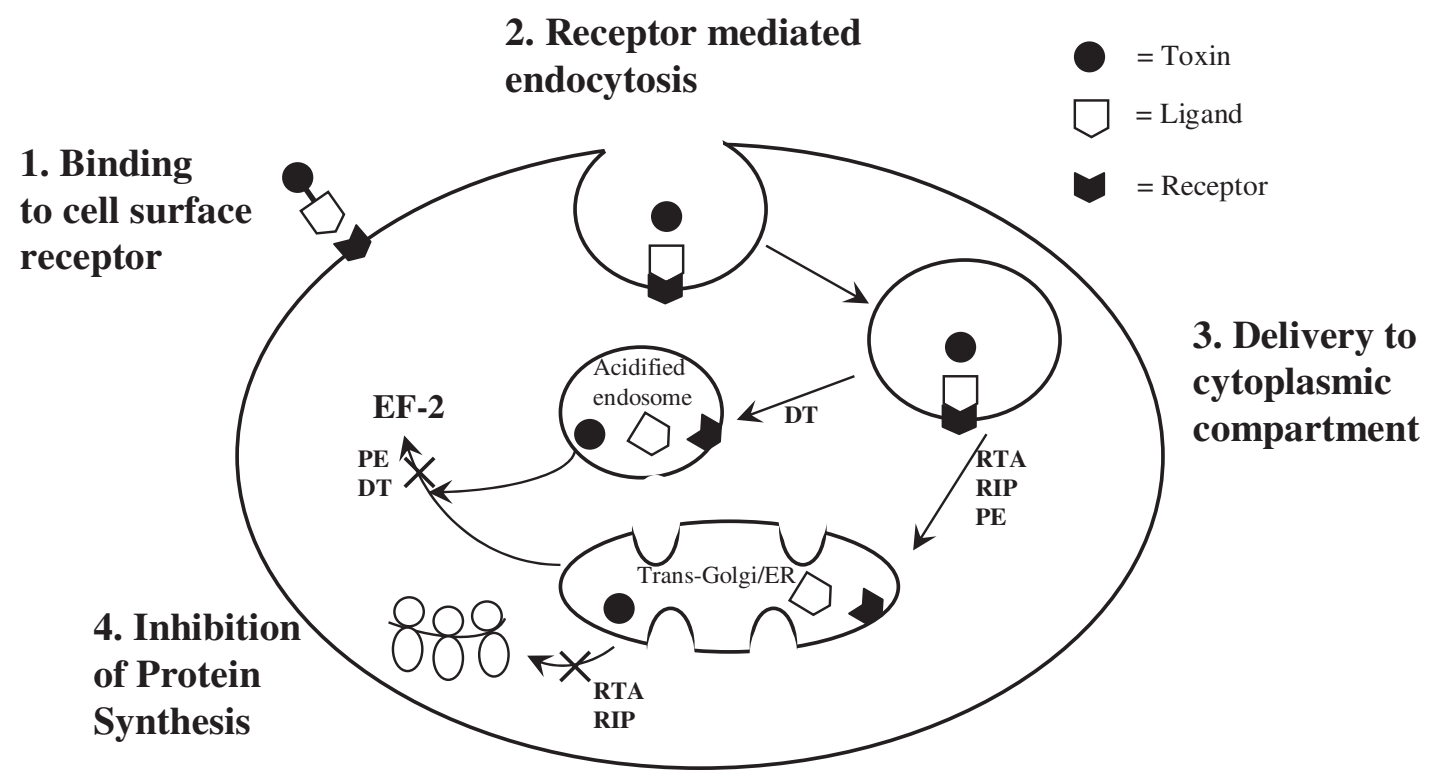

Figure 5 Mechanism by which hormonotoxins may lead to cell death. The ligand-toxin conjugate binds to specific receptors on the surface of target cells (1) and is then internalized via receptor-mediated endocytosis (2). Once inside the cell, the conjugate (or the toxin alone) enters the cytoplasm by an unknown mechanism (3) and inhibits protein synthesis; the mechanism by which this occurs depends on the type of toxin. Pseudomonas exotoxin (PE) and diphtheria toxin (DT) inactivate elongation factor-2 (EF-2), whereas plant toxins (ricin toxin A (RTA); ribosome-inactivating protein (RIP)) inactivate 28S RNA. In either case, the intoxicated cell is unable to synthesize proteins which results in cell death. (Adapted with permission from Thrush et al. (1996)).

cytotoxins, has been developed to destroy specific tissue or cell types in the body. In the initial studies, antibodies specific for a particular cell or tissue were generated and conjugated to bacterial or plant toxins (Collier \& Kaplan 1984). Following binding of the antibody-toxin conjugate to a molecular target on the cell surface, it is internalized into endosomes. In the case of many plant and bacterial toxins, acidification results in conformational changes in the toxin that permit it to exit the endosome and enter the cytoplasm. Once in the cytoplasm, most toxins inhibit protein synthesis, eventually leading to cell death, reviewed by Thrush et al. (1996) (Fig. 5). Many immunotoxins have been developed to target specific tumors based on unique cell-surface targets discovered through the use of monoclonal antibodies. Whereas cytotoxic small molecules can be delivered by such antibodies, the advantage of toxic proteins such as diphtheria toxin (DT), pokeweed antiviral protein (PAP) and Pseudomonas exotoxin (PE) lies in their enzymatic activity such that a single molecule specifically delivered to a target cell may have a much greater intracellular influence, potentially acting on thousands of substrate molecules within a cell. Thus, compared with traditional chemotherapeutic agents, only a small fraction of the number of molecules needs be delivered to cause cytotoxicity. In the past decade, targeted toxin therapy has been employed in numerous human clinical and animal studies (Brinkmann \& Pastan 1994, Bast et al. 1996,
Nichols et al. 1997, Frankel et al. 2000, Olsen et al. 2001, Allen 2002, Abou-Jawde et al. 2003) and some agents have been approved by the FDA for use in patients (Gunther et al. 1993, Bast et al. 1996, Nichols et al. 1997, Uckun et al. 1999, Olsen et al. 2001, Abou-Jawde et al. 2003).

\section{Studies with hormonotoxins}

More recently, a similar approach has been the use of hormones rather than antibodies to target toxins to specific cells in the body (Schwartz et al. 1987, Singh \& Curtiss 1991, 1994, Marcil et al. 1993). With this approach, a toxin is conjugated to a hormone that has specific receptors in a select population of target cells. The 'hormonotoxin' then binds to those receptors, is taken into the cell by receptor-mediated endocytosis and, when delivered to the cytoplasm, results in inhibition of protein synthesis leading to cell death.

Among peptide hormones, cytotoxic analogs of somatostatin, bombesin and GnRH have been synthesized in a program headed by Andrew Schally (Letsch et al. 2003). These compounds have shown efficacy in ovarian, breast and renal cell carcinoma cell lines, and xenograft models. Receptors for somatostatin have been demonstrated on breast, kidney, brain and non-small cell lung cancers, and radiolabeled ${ }^{90} \mathrm{Y}$ or ${ }^{111}$ In somatostatin analogs have been used for both imaging and therapy 
(Virgolini et al. 2002). Additionally, a hormonotoxin utilizing corticotropin-releasing hormone $(\mathrm{CRH})$ as the targeting agent was reported to decrease the ability of pituitary cells to respond to CRH (Schwartz et al. 1987, Schwartz \& Vale 1988). Thus, this approach appears to have utility for numerous hormone receptors.

As discussed previously and reviewed elsewhere, elimination of gonadal function is an effective therapy for prostate and breast cancers (Miller et al. 1985, Vickery 1986, Nicholson \& Walker 1989, Hoffken 1992, Weinbauer \& Nieschlag 1992), and for other hormonedependent abnormalities including fibroid tumors and endometriosis. GnRH analogs have successfully replaced surgery in a number of settings such as metastatic breast or prostate cancers, and their reversibility is particularly useful in settings where return of gonadal function is desirable. On the other hand, in many instances, for example, the ongoing maintenance of the castrate state after a prostate cancer patient becomes 'hormone refractory', permanent castration would be preferable. Development of a non-surgical agent that resulted in permanent suppression of gonadal activity after a single administration would thus constitute a major advance in the treatment of hormone-dependent tumors.

Potentially, hormonotoxins could be developed to attack the gonadal cells directly by attaching toxins to gonadotropins (Marcil et al. 1993, Singh \& Curtiss 1994). If attached to $\mathrm{LH}$, the toxin could potentially destroy Leydig cells in males, and theca, granulosa and luteal cells in females. Since theca and granulosa cells do not acquire $\mathrm{LH}$ receptors until development of a follicle is relatively advanced (i.e. follicles in early stages of development would not be affected), and since the corpus luteum is a transient endocrine organ, an LH-toxin conjugate would not lead to permanent castration in females. Likewise, in males there appears to be a stem cell population that will replace Leydig cells if they are destroyed (Keeney et al. 1990). Thus, an LH-toxin conjugate would only lead to a transient decrease in testicular function. If attached to $\mathrm{FSH}$, again the toxin may lead to destruction of granulosa cells in follicles thus preventing follicular development. However, primordial and primary follicles do not have FSH receptors (Fortune et al. 1991) so as soon as the FSH-toxin conjugate is cleared from the blood stream, follicle maturation would resume. An FSH-toxin conjugate in males may result in destruction of Sertoli cells and lead to aspermia. However, the number of Sertoli cells in the adult testis is not static, at least in some species of animals (Johnson \& Thompson 1983). Since Sertoli cells appear capable of dividing in adult males, it seems unlikely that the effects of an FSH-toxin in males would be permanent. Further, Leydig cells would be unaffected. Therefore, testosterone secretion would continue una- bated and androgenic stimulation of hormone-dependent tumors would continue. Thus, an FSH-toxin conjugate also would not be useful for inducing permanent gonadal inactivity. For these reasons, 'chemical castration' using gonadotropin-toxin conjugates does not appear feasible.

To circumvent problems inherent with the use of $\mathrm{LH}$ and/or FSH, a hormontoxin using GnRH as the targeting agent to achieve chemical castration would appear preferable. The GnRH-toxin would not target the gonads directly, but rather destroy gonadotropes in the anterior pituitary gland, the cells that produce the hormones (FSH and $\mathrm{LH}$ ) responsible for stimulating gonadal activity. Gonadotropes appear to be a terminally differentiated cell line, so destruction of gonadotropes would potentially lead to a permanent loss of gonadal function. Some of the GnRH-toxin approaches used to date have not been permanently toxic to the pituitary gonadotropes. This may be due to the relatively resting G0 state of these cells and the high amounts of toxin moieties such as the doxorubicin analogs required when compared with the enzymatic toxins. On the other hand, use of PE as the toxin in conjugates has been associated with dose-limiting CNS toxicity (Pai et al. 1992).

There are several additional reasons why GnRH is a superior choice to the use of gonadotropins to eliminate gonadal activity: (1) GnRH is a relatively small peptide (10 amino acids) that can be prepared by chemical synthesis in large quantities for nominal cost, (2) GnRH functions similarly in both males and females so a single compound could be used in either sex, (3) numerous analogs of GnRH are available that have much higher affinity for receptors than native GnRH thus enhancing the probability that the hormone-toxin conjugate will bind to receptor, (4) the GnRH molecule can be easily modified to produce analogs that can be readily linked to toxins and (5) there is little evidence that gonadotropes actively divide once puberty has occurred; thus, if existing gonadotropes are destroyed, it does not seem likely that they will be replaced. Gonadotropins are essential for gonadal function, so this would lead to permanent gonadal inactivity in both males and females. In addition, tumor cells that aberrantly express GnRHRs could be directly affected by such a conjugate as discussed above. Therefore, it is possible that for some hormone-sensitive tumors, both direct (via GnRHRs expressed in tumors) and indirect (via reduction in sex steroids by elimination of gonadotropin secretion) effects on the tumor could be achieved.

Several investigators have attempted to develop GnRH-toxin conjugates that destroy gonadotropes. Myers \& Villemez (1989) conjugated GnRH to DT toxin, but they did not report its bioactivity. Szoke et al. (1994) reported that a GnRH agonist conjugated to glutaryl-2-(hydroxymethyl)-anthraquinone, a cytotoxic 
agent, was internalized by rat pituitary cells in vitro, a necessary step for causing cell death. More recently, it was reported (Kovacs et al. 1997) that a GnRH agonist conjugated to 2-pyrrolinodoxorubicin, a highly potent cytotoxic agent, decreased GnRH-stimulated LH secretion in rats by $63 \%$ whereas thyrotropin-releasing hormone-induced thyrotropin secretion and GHRHinduced growth hormone secretion were not significantly affected. However, their study lasted for less than 60 days so whether the reduction in gonadotrope function induced by the GnRH-toxin was permanent or temporary was not ascertained. Moreover, chemotherapeutic agents like glutaryl-2-(hydroxymethyl)anthraquinone and 2-pyrrolinodoxorubicin have two disadvantages compared with agents such as DT or similar compounds. First, even though GnRH will facilitate localization to gonadotropes, there is a significant potential for non-specific toxicity because any cell in the body could still take up the conjugate in small amounts due to the chemical nature of the chemotherapeutic agents. Secondly, many chemotherapeutic agents such as the anthracyclines must intercalate into DNA to disrupt cellular function. Potentially thousands of molecules may therefore have to be delivered to a cell to inhibit its function completely. In contrast, the enzymatic activity of some plant and bacterial toxins renders them much more efficacious once internalized. In fact, one molecule of DT has been reported to inactivate as many as five million molecules of elongation factor 6 in cells (Collier \& Kaplan 1984).

If $\mathrm{GnRH}$-cytotoxins actually destroy gonadotropes as they should do theoretically, then it is possible that a single dose could lead to permanent suppression of gonadal function in an individual with steroid-responsive prostate or breast cancer. Thus, these compounds would alleviate the need for repeated and continual treatment as is necessary with the GnRH agonists and antagonists in use today. Therefore, GnRH-cytotoxins have the potential to significantly decrease the number of times an individual will need to travel to a clinic to obtain treatment and decrease the lifetime cost of such treatments. In addition to these advantages, many breast and prostate cancers actually express receptors for GnRH and GnRH-cytotoxins have the potential to specifically bind to those receptors and destroy cancer cells, something that GnRH agonists or antagonists cannot do. This is discussed in greater detail in the next section of this review.

\section{Potential use of GnRH-toxins for prostate, breast and ovarian cancers}

Although GnRH analog therapy will suppress gonadotropin (and therefore ovarian/testicular steroid hormone) production and thereby slow progression of breast or prostate cancers, many such tumors also appear to have receptors for GnRH (as discussed above). Thus, the potential exists for these cells to respond directly to hormonotoxin treatment using $\mathrm{GnRH}$ as the targeting ligand. Ovarian cancer cells, although not responsive to steroid hormones, express the GnRHR and their growth is inhibited by $\mathrm{GnRH}$ analog treatment.

\section{Comparison of fusion and conjugate $\mathrm{GnRH}-$ toxins}

Fusion proteins consisting of GnRH and PAP or PE have been produced and shown to inhibit growth of cultured tumor cells expressing GnRHRs (Nechushtan et al. 1997, Schlick et al. 2000); however, the activity of the fusion proteins were not directly compared with the activities of hormonotoxins produced by conjugation of a $\mathrm{GnRH}$ analog to the toxic protein moiety. Since recombinant fusion proteins are not chemically synthesized, they should always have one and only one GnRH associated with each PAP molecule, and it is always at the same site. For this reason, the uniformity of GnRH-PAP fusion preparations should be much better than for conjugates prepared by chemical means, thus making the generation of large amounts of GnRH-PAP for clinical studies more feasible. It is likely, however, that recombinant fusion proteins will have inferior activity to hormontoxins produced via chemical conjugation for two reasons: (1) the ends of the GnRH molecule are known to be important for receptor binding (Karten \& Rivier 1986) and are not likely to be as easily accessible to the receptor in a fusion protein and (2) the incorporation of a D-amino acid in position 6 that is known to enhance receptor binding affinity approximately 30 -fold is impossible in fusion proteins.

We recently compared GnRH-PAP fusion toxin (single polypeptide chain) with GnRH-PAP chemical conjugate for binding and cytotoxic activity in Chinese hamster ovary $(\mathrm{CHO})$ control cells, and $\mathrm{CHO}$ cells expressing a transfected GnRHR (CHO-GnRHR) (Qi et al. 2004). In support of the hypothesis that the conjugate would be more cytotoxic than the fusion protein, we showed that while the conjugate bound and caused specific toxicity to GnRHR-positive cells, the GnRHPAP fusion proteins were much less active in both of these regards. We tested two different versions of fusion protein, corresponding to either full (f, containing posttranslationally modified sequences) or mature ( $\mathrm{m}$, without these sequences). GnRH-fPAP was tested because a previous study (Schlick et al. 2000) demonstrated that a GnRH-PAP fusion protein containing these post-translationally modified sequences was cytotoxic to Ishikawa cells (an endometrial cell line). While the GnRH-PAP conjugate bound to GnRHR, albeit at somewhat higher 

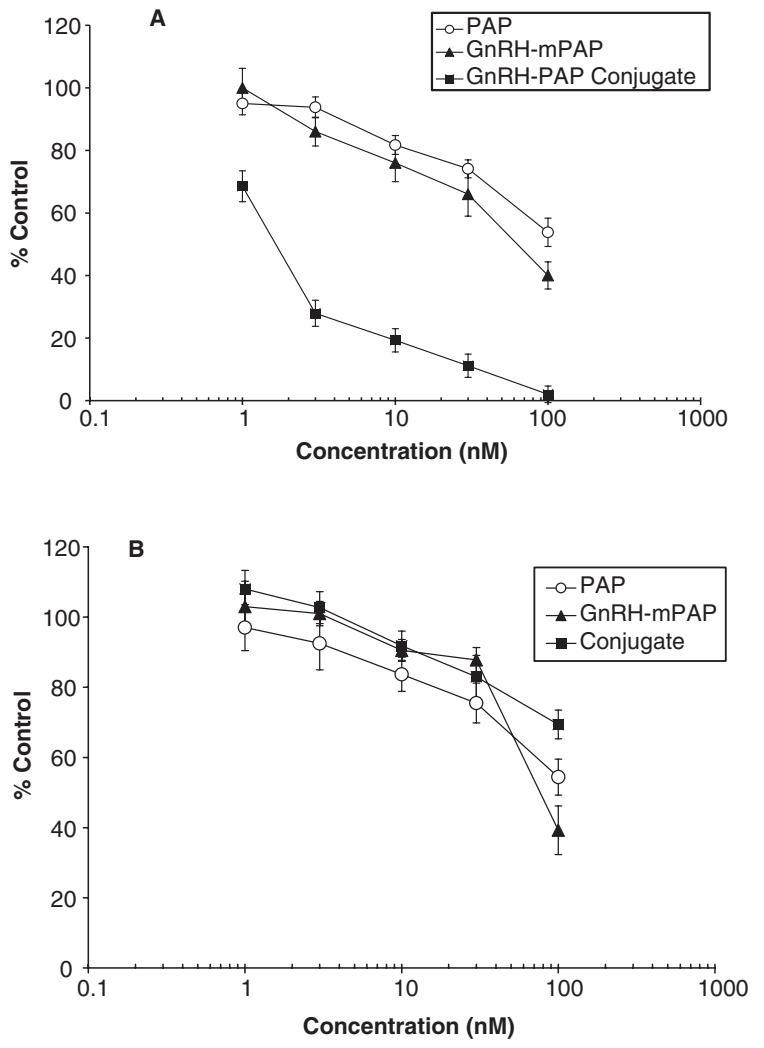

Figure 6 Clonogenic assay in (A) $\mathrm{CHO}-\mathrm{GnRHR}$ or (B) $\mathrm{CHO}$ control cells exposed to varying concentrations of PAP, GnRHmPAP fusion protein or GnRH-PAP conjugate. Values are means \pm S.E.M. (Reprinted with permission from Qi et al. 2004).

concentrations compared with control GnRH alone (DLys ${ }^{6}-\mathrm{GnRH}$ ), neither of the fusion proteins (GnRH-fPAP or GnRH-mPAP) were able to inhibit binding of the radioligand to GnRHR. However, both the GnRH-PAP conjugate and GnRH-mPAP fusion proteins inhibited translation to a similar extent as PAP alone in a cell-free rabbit reticulocyte translation system, demonstrating that the PAP molecule in the conjugate and fusion proteins retained toxicity. Thus, any difference in their cytotoxicity when tested in cell survival/clonogenic assays could not be attributed to disruption of PAP function.

To evaluate the ability of GnRH-PAP to inhibit growth of cells expressing GnRHR on their surface, cells were treated with increasing amounts of PAP or GnRHPAP conjugate or fusion protein. We showed that GnRH-PAP was able to prevent the growth of cells expressing GnRHRs including several prostate and breast cancer cell lines (Qi et al. 2003, Yang et al. 2003). Results from a clonogenic assay (consisting of counting the number of colonies formed at the end of a 5-day incubation period) are shown in Fig. 6 in control $\mathrm{CHO}$ and CHO-GnRHR cells. As seen in the figure, PAP and
GnRH-mPAP fusion showed only non-specific toxicity, with similar results in both $\mathrm{CHO}$ and $\mathrm{CHO}-\mathrm{GnRHR}$ cells at all concentrations $(P>0.1$, comparing GnRH-mPAP to PAP alone at $\left.1 \times 10^{-8} \mathrm{M}\right)$. Fifty percent inhibition in both cell types with these proteins was observed only at concentrations $>100 \mathrm{nM}$. In contrast, GnRH-PAP conjugate protein showed specific toxicity in CHO-GnRHR cells $\left(P<0.002\right.$ at $1 \times 10^{-8} \mathrm{M}$ compared with PAP alone), with $50 \%$ inhibition seen at approximately $2 \mathrm{nM}$; in $\mathrm{CHO}$ controls cells, toxicity from the conjugate protein was within the same concentration range as the fusion protein and PAP $\left(P>0.09\right.$ at $\left.1 \times 10^{-8} \mathrm{M}\right)$. These results showed that the conjugate protein was approximately 50 -fold more cytotoxic to CHO-GnRHR cells compared with $\mathrm{CHO}$ control cells. The fusion protein, however, did not show any specific toxicity to CHO-GnRHR cells. This finding is consistent with the lack of fusion protein binding to GnRHR.

Although the native GnRH sequence was used in the fusion proteins while the analog GnRH (with D-amino acid in position 6 , see above) was used in the conjugate protein, the difference in binding affinity (30-fold) by itself was not sufficient to explain the three to four log difference in binding between conjugate and fusion GnRH-PAP proteins, nor the approximate two log difference in cytotoxicity.

\section{GnRH-toxin conjugates in cancer cell lines}

With this information in hand, we decided to evaluate GnRH-PAP prepared by chemical conjugation both in vivo and in vitro. Two sets of studies were performed to evaluate this conjugate in vitro. First, ovine anterior pituitary glands were dissociated into single cells and placed in cell culture. Cultured cells served as controls or were treated with PAP alone, or with GnRH-PAP overnight. Following the overnight culture, treatments were removed by washing the cells with media and then the cells were incubated for an additional $24 \mathrm{~h}$. At this time, the cells were collected, homogenized and amounts of $\mathrm{LH}$ (to reflect gonadotrope activity) and prolactin (to assess activity in a cell type not expressing GnRHRs) were measured. PAP alone did not alter the amounts of either LH or prolactin in the pituitary cells compared with controls. However, GnRH-PAP decreased the amount of LH in the cells by approximately $80 \%$ compared with the controls, but did not alter the amount of prolactin in the cells (Fig. 7). Secondly, we tested the chemical GnRHPAP conjugate against selected cancer cell lines for direct toxicity. As shown in Fig. 8, both $\mathrm{CHO}$ cells expressing the GnRHR and $\alpha$ T3-1 cell lines were specifically killed by the conjugate at concentrations greater than $10 \mathrm{nM}$ (Yang et al. 2003). We also demonstrated direct GnRH-PAP cytotoxicity in prostate cancer cell lines (Qi et al. 2003). 


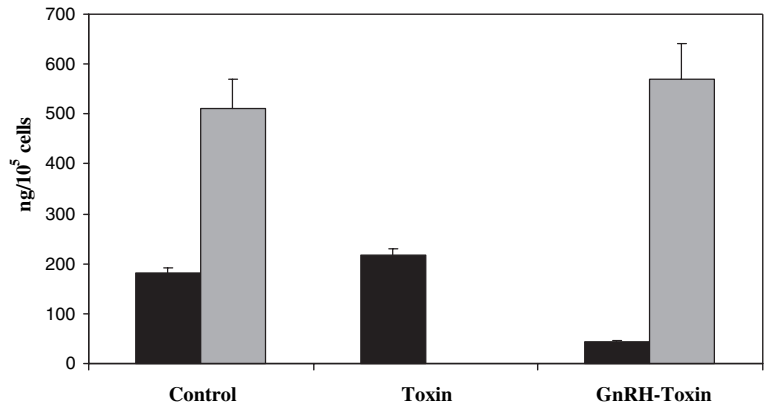

Figure 7 Effects (means \pm S.E.M.) of GnRH-toxin or toxin alone on the ability of cultured anterior pituitary cells to synthesize LH (solid bars) or prolactin (shaded bars). Toxin alone did not alter LH synthesis compared with untreated cells, but GnRH-toxin substantially decreased $(P<0.01)$ synthesis of $\mathrm{LH}$. In contrast, $\mathrm{GnRH}$-toxin did not influence the ability of cultured pituitary cells to synthesize prolactin $(P>0.05)$.

These data demonstrate the ability of this conjugate to specifically inhibit the function of cells expressing GnRHRs without altering the function of cells lacking GnRHRs. Moreover, the pituitary cells that were affected are the cells responsible for stimulating the activity of gonads. Thus, inhibiting the function of these cells would eliminate the gonadal steroids on which many prostate and mammary tumors are dependent for their growth. As GnRH agonists alone will not result in sterilization, the ability to achieve this is an important avenue of investigation. The potential for use of this conjugate in clinical trials will clearly depend on the level of expression of the GnRHR in vivo, quantification of which is a current focus of our laboratories.

\section{GnRH-toxin conjugates in animal studies}

Encouraged by the results obtained in the experiments discussed above, the GnRH-PAP conjugate was next tested in vivo. In this study, the effect of GnRH-PAP on reproductive function was evaluated in adult, male dogs. Four dogs received GnRH-PAP hourly for 36 h (hourly) and four other dogs received GnRH-PAP as one bolus injection daily for 3 consecutive days (bolus). One dog received a single bolus (single). Three adult male dogs received GnRH without the PAP conjugate and served as controls. Twenty-five weeks after the initial treatment, all treated dogs received a second treatment with GnRH-PAP as a single bolus while control dogs received GnRH. Serum concentrations of testosterone and $\mathrm{LH}$ were determined by radioimmunoassay, and testis size was measured for 9 months after treatment. Stimulation tests $(5 \mu \mathrm{g} / \mathrm{kg} \mathrm{GnRH})$ were used to evaluate the ability of the pituitary gland to release LH. Serum
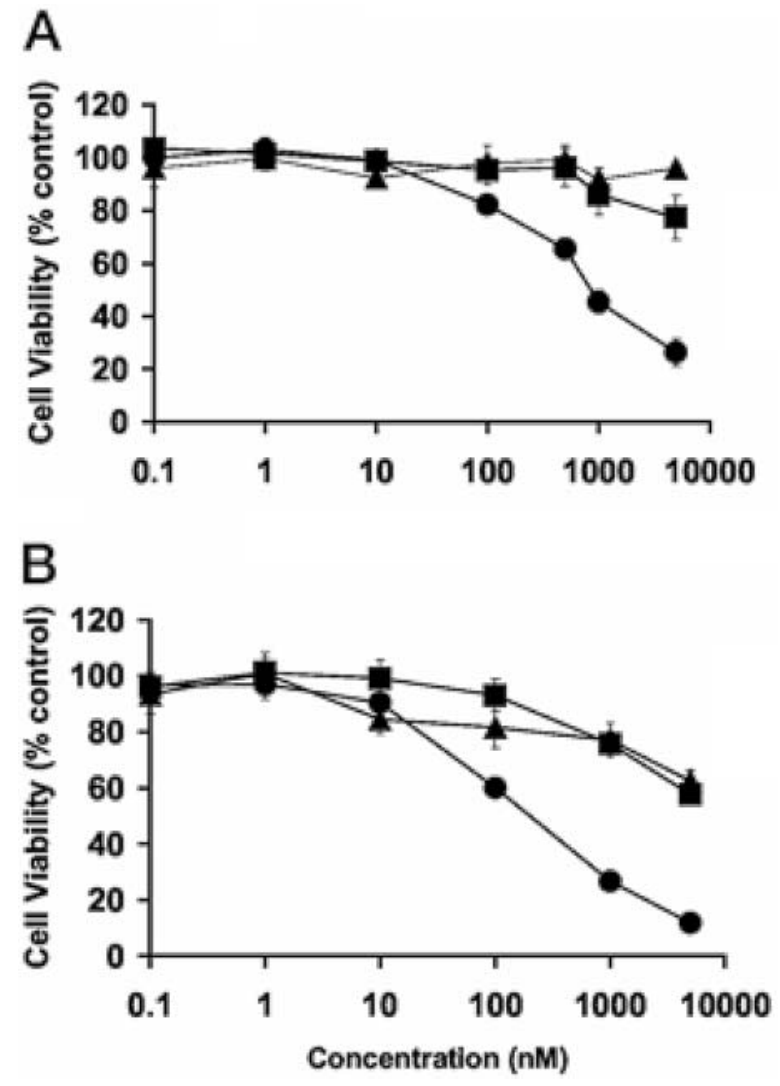

Figure 8 Cytotoxicity of GnRH-PAP conjugate against (A) $\mathrm{CHO}-\mathrm{GnRHR}$ and (B) $\alpha \mathrm{T} 3-1$ cells in the cell proliferation assay, with various concentrations of GnRH-PAP (O), D-Lys ${ }^{6}-\mathrm{GnRH}$ $(\boldsymbol{\Delta})$ or PAP $(\boldsymbol{\square})$. Values are means \pm S.E.M. (Reprinted with pemission from Yang et al. (2003)).

testosterone concentrations were measured to evaluate testis function during the study. Concentrations of testosterone were significantly lower $(P<0.05)$ in all animals treated with GnRH-PAP than in controls after treatment (Fig. 9A). Basal LH was lower $(P<0.05)$ in all treated animals than in the control group between weeks 0 and 33 post-treatment. Likewise, treatment with GnRH-PAP reduced $(P<0.05)$ LH release after GnRH stimulation in treated animals compared with the control area under the curve (AUC) (Fig. 9B). Testis volume was lower $(P<0.05)$ in all treated versus control dogs (Fig. 9C). In conclusion, administration of the GnRH-PAP conjugate at a 25 -week interval resulted in a major disruption of reproductive function in male dogs which was maintained for at least 11-12 weeks after the second GnRH-PAP injection (Sabeur et al. 2003).

In all animal and human studies to date from our group and others, there has been no evidence for 


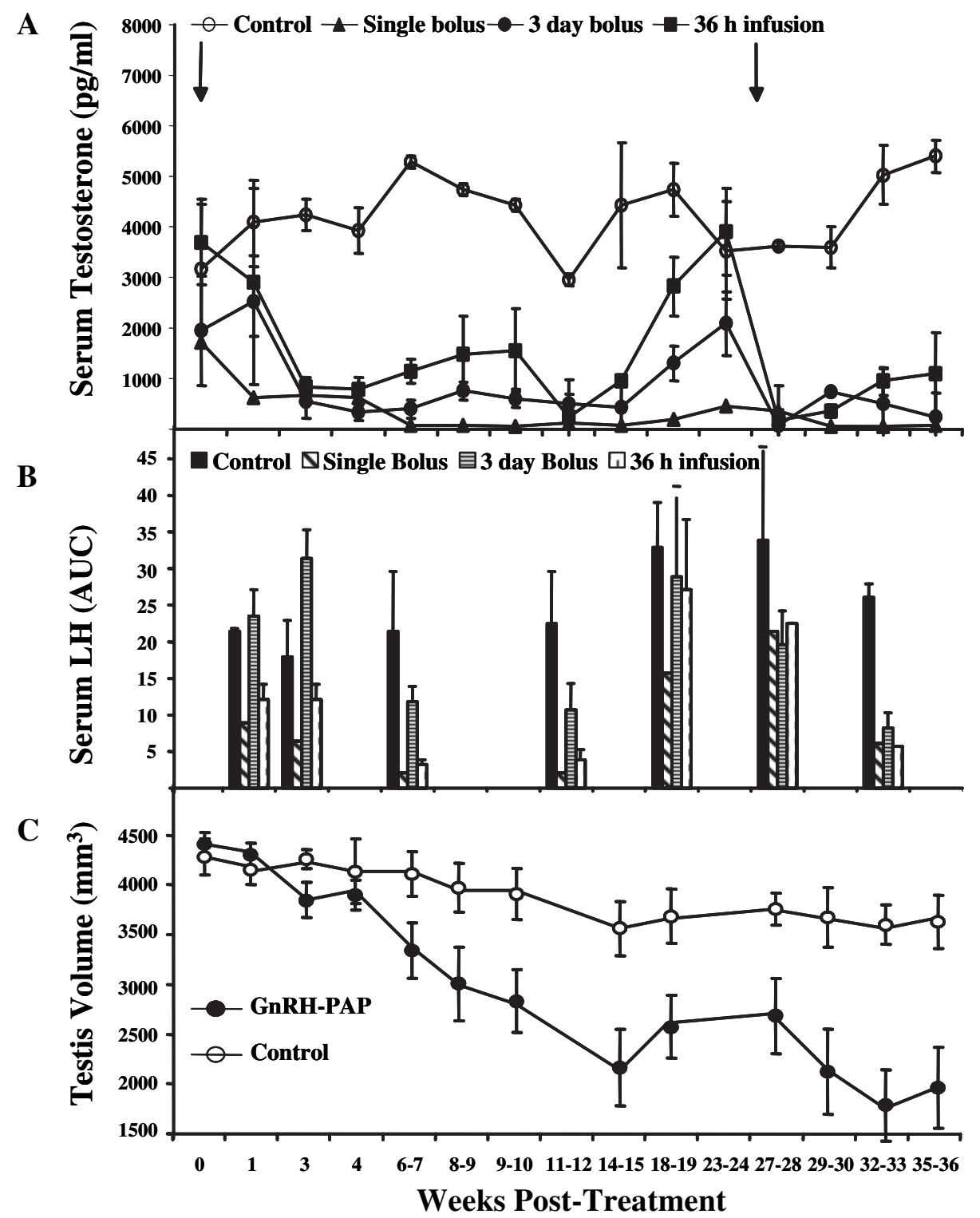

Figure 9 Effects (means \pm S.E.M.) of GnRH-PAP on reproductive parameters in male dogs. Treatment regimens are described in the text. Arrows in (A) indicate the times that treatments were administered. (A) Changes in serum concentrations of testosterone at various times after treatments. The ability of the anterior pituitary to respond to a $\mathrm{GnRH}$ challenge is shown in (B); data shown represent the total amount of $\mathrm{LH}$ released (AUC) following the challenge. Changes in testicular volume with time after treatments is depicted in (C). Since each of the treatment regimens resulted in decreased testicular volume, data from all the treatment groups were combined. (Reprinted with pemission from Sabeur et al. 2003)).

non-specific toxicity, nor any indication that removal of GnRH inhibited the function of a variety of organs in which mRNA for GnRH receptor has been identified (i.e. gut). The fact that administration of GnRH-PAP or immunization to eliminate active GnRH from the circulation only affects reproductive tissues supports the premise that GnRHR can be safely employed as the target for hormonotoxins.

\section{Conclusions and future prospects}

Over three decades have passed since the elucidation of the GnRH molecule. Analogs are now widely employed in the treatment of prostate cancer, eliminating the need for surgical castration, and ongoing studies suggest similar benefits in selected breast cancer patients. The expression of GnRHR-I and GnRHR-II in peripheral tissues, 
especially neoplastic tissues, may provide a new target for GnRH-toxin-directed therapy. This treatment could potentially achieve both permanent castration by elimination of pituitary gonadotropes as well as direct cytotoxicity to tumors. Animal studies to date support such development, revealing little toxicity to normal intact tissues, while clinical studies will depend on the development and testing of good manufacturing practices (GMP) materials. The elucidation of the differences in function of the GnRH-I and GnRH-II receptors and ligands remains an area of intense investigation.

\section{Acknowledgements}

LMG and TMN are co-founders of Gonex (http:// www.gonex.com), a corporation attempting to commercialize GnRH-toxin conjugates for cancer therapy and other applications. GSH is a minor stockholder in Gonex.

\section{References}

Abou-Jawde R, Choueiri T, Alemany C \& Mekhail T 2003 An overview of targeted treatments in cancer. Clinical Therapeutics 25 2121-2137.

Albertsen PC, Fryback DG, Storer BE, Kolon TF \& Fine J 1995 Long-term survival among men with conservatively treated localized prostate cancer. Journal of the American Medical Association 274 626-631.

Allen TM 2002 Ligand-targeted therapeutics in anticancer therapy. Nature Reviews of Cancer 2 750-763.

Anonymous 1984 Leuprolide versus diethylstilbestrol for metastatic prostate cancer. The Leuprolide Study Group. New England Journal of Medicine 311 1281-1286.

Anonymous 1996 Ovarian ablation in early breast cancer: overview of the randomised trials. Early Breast Cancer Trialists' Collaborative Group. Lancet 348 1189-1196.

Anonymous 2000 Maximum androgen blockade in advanced prostate cancer: an overview of the randomised trials. Prostate Cancer Trialists' Collaborative Group. Lancet 355 1491-1498.

Anonymous 2003 Urologists face major cut in AWP of cancer drugs. Urology Times (1 December).

Avila DM, Zoppi S \& McPhaul MJ 2001 The androgen receptor (AR) in syndromes of androgen insensitivity and in prostate cancer. Journal of Steroid Biochemistry and Molecular Biology $76135-142$

Bahk JY, Hyun JS, Chung SH, Lee H, Kim MO, Lee BH \& Choi WS 1995 Stage specific identification of the expression of GnRH mRNA and localization of the GnRH receptor in mature rat and adult human testis. Journal of Urology $\mathbf{1 5 4}$ 1958-1961.

Barbieri RL 1998 Endometriosis and the estrogen threshold theory. Relation to surgical and medical treatment. Journal of Reproductive Medicine 43 287-292.
Bast R, Zalutsky M \& Frankel A 1996 Monoclonal serotherapy. In Cancer Medicine, Edn 4 pp 1245-1262. Eds J Holland, E Frei, R Bast, D Morton, D Kufe \& R Weichselbaum. Baltimore: Williams and Wilkins.

Bedecarrats GY \& Kaiser UB 2003 Differential regulation of gonadotropin subunit gene promoter activity by pulsatile gonadotropin-releasing hormone $(\mathrm{GnRH})$ in perifused L beta T2 cells: role of GnRH receptor concentration. Endocrinology 144 1802-1811.

Ben-Yehudah A, Yarkoni S, Nechushtan A, Belostotsky R \& Lorberboum-Galski H 1999 Linker-based GnRH-PE

chimeric proteins inhibit cancer growth in nude mice. Medical Oncology 16 38-45.

Boccardo F, Blamey R, Klijn JG, Tominaga T, Duchateau L \& Sylvester R 1999 LHRH-Agonist (LHRH-A) + tamoxifen (TAM) versus LHRH-A alone in premenopausal women with advanced breast cancer (ABC): results of a meta-analysis of four trials. Proceedings of the American Society of Clinical Oncology 18 110a (Abstract).

Bolla M, Gonzalez D, Warde P, Dubois JB, Mirimanoff RO, Storme G, Bernier J, Kuten A, Sternberg C, Gil T et al. 1997 Improved survival in patients with locally advanced prostate cancer treated with radiotherapy and goserelin. New England Journal of Medicine 337 295-300.

Bono AV, Salvadore M \& Celato N 2002 Gonadotropinreleasing hormone receptors in prostate tissue. Analytical and Quantitative Cytology and Histology 24 221-227.

Borroni R, Di Blasio AM, Gaffuri B, Santorsola R, Busacca M, Vigano P \& Vignali M 2000 Expression of GnRH receptor gene in human ectopic endometrial cells and inhibition of their proliferation by leuprolide acetate. Molecular and Cellular Endocrinology 159 37-43.

Botte MC, Chamagne AM, Carre MC, Counis R \& Kottler ML 1998 Fetal expression of GnRH and GnRH receptor genes in rat testis and ovary. Journal of Endocrinology 159 179-189.

Botte MC, Lerrant Y, Lozach A, Berault A, Counis R \& Kottler ML 1999 LH down-regulates gonadotropin-releasing hormone $(\mathrm{GnRH})$ receptor, but not $\mathrm{GnRH}$, mRNA levels in the rat testis. Journal of Endocrinology 162 409-415.

Brinkmann U \& Pastan I 1994 Immunotoxins against cancer. Biochimica et Biophysica Acta 1198 27-45.

Buzdar AU 2004 Data from the Arimidex, tamoxifen, alone or in combination (ATAC) trial: implications for use of aromatase inhibitors in 2003. Clinical Cancer Research 10 355S-361S.

Castiglione-Gertsch M, O’Neill A, Price KN, Goldhirsch A, Coates AS, Colleoni M, Nasi ML, Bonetti M \& Gelber RD 2003 Adjuvant chemotherapy followed by goserelin versus either modality alone for premenopausal lymph nodenegative breast cancer: a randomized trial. Journal of the National Cancer Institute 95 1833-1846.

Chatzaki E, Bax CM, Eidne KA, Anderson L, Grudzinskas JG \& Gallagher CJ 1996 The expression of gonadotropin-releasing hormone and its receptor in endometrial cancer, and its relevance as an autocrine growth factor. Cancer Research $\mathbf{5 6}$ 2059-2065.

Chen A, Ganor Y, Rahimipour S, Ben-Aroya N, Koch Y \& Levite M 2002 The neuropeptides GnRH-II and GnRH-I are produced by human $\mathrm{T}$ cells and trigger laminin receptor gene 
expression, adhesion, chemotaxis and homing to specific organs. Nature Medicine 8 1421-1426.

Cheng CK, Yeung CM, Chow BK \& Leung PC 2002 Characterization of a new upstream GnRH receptor promoter in human ovarian granulosa-luteal cells. Molecular Endocrinology 16 1552-1564.

Chodak GW, Vogelzang NJ, Caplan RJ, Soloway M \& Smith JA 1991 Independent prognostic factors in patients with metastatic (stage D2) prostate cancer. The Zoladex Study Group. Journal of the American Medical Association 265 618-621.

Chon JK, Jacobs SC \& Naslund MJ 2000 The cost value of medical versus surgical hormonal therapy for metastatic prostate cancer. Journal of Urology 164 735-737.

Chou CS, MacCalman CD \& Leung PC $2003 a$ Differential effects of gonadotropin-releasing hormone I and II on the urokinasetype plasminogen activator/plasminogen activator inhibitor system in human decidual stromal cells in vitro. Journal of Clinical Endocrinology and Metabolism 88 3806-3815.

Chou CS, Tai CJ, MacCalman CD \& Leung PC 2003b Dosedependent effects of gonadotropin releasing hormone on matrix metalloproteinase (MMP)-2, and MMP-9 and tissue specific inhibitor of metalloproteinases-1 messenger ribonucleic acid levels in human decidual stromal cells in vitro. Journal of Clinical Endocrinology and Metabolism 88 680-688.

Chou CS, Zhu H, MacCalman CD \& Leung PC 2003 c Regulatory effects of gonadotropin-releasing hormone (GnRH) I and GnRH II on the levels of matrix metalloproteinase (MMP)-2, MMP-9, and tissue inhibitor of metalloproteinases-1 in primary cultures of human extravillous cytotrophoblasts. Journal of Clinical Endocrinology and Metabolism 88 4781-4790.

Clayton RN \& Catt KJ 1981 Gonadotropin-releasing hormone receptors: characterization, physiological regulation, and relationship to reproductive function. Endocrine Reviews 2 186-209.

Collier RJ \& Kaplan DA 1984 Immunotoxins. Scientific American 251 56-64.

Crawford ED 2003 Early versus late hormonal therapy: debating the issues. Urology 61 8-13.

Crump M, Sawka CA, DeBoer G, Buchanan RB, Ingle JN, Forbes J, Meakin JW, Shelley W \& Pritchard KI 1997 An individual patient-based meta-analysis of tamoxifen versus ovarian ablation as first line endocrine therapy for premenopausal women with metastatic breast cancer. Breast Cancer Research and Treatment 44 201-210.

Davidson L, Pawson AJ, Millar RP \& Maudsley S 2004 Cytoskeletal reorganization dependence of signaling by the gonadotropin-releasing hormone receptor. Journal of Biological Chemistry 279 1980-1993.

Densmore VS \& Urbanski HF 2003 Relative effect of gonadotropin-releasing hormone (GnRH)-I and GnRH-II on gonadotropin release. Journal of Clinical Endocrinology and Metabolism 88 2126-2134.

Dufau ML, Warren DW, Knox GF, Loumaye E, Castellon ML, Luna S \& Catt KJ 1984 Receptors and inhibitory actions of gonadotropin-releasing hormone in the fetal Leydig cell. Journal of Biological Chemistry 259 2896-2899.
Ellsworth BS, White BR, Burns AT, Cherrington BD, Otis AM \& Clay CM 2003a c-Jun N-terminal kinase activation of activator protein-1 underlies homologous regulation of the gonadotropin-releasing hormone receptor gene in alpha T3-1 cells. Endocrinology 144 839-849.

Ellsworth BS, Burns AT, Escudero KW, Duval DL, Nelson SE \& Clay CM 2003b The gonadotropin releasing hormone $(\mathrm{GnRH})$ receptor activating sequence (GRAS) is a composite regulatory element that interacts with multiple classes of transcription factors including Smads, AP-1 and a forkhead DNA binding protein. Molecular and Cellular Endocrinology 206 93-111.

Emons G \& Schally AV 1994 The use of luteinizing hormone releasing hormone agonists and antagonists in gynaecological cancers. Human Reproduction 9 1364-1379.

Emons G, Schroder B, Ortmann O, Westphalen S, Schulz KD \& Schally AV 1993 High affinity binding and direct antiproliferative effects of luteinizing hormone-releasing hormone analogs in human endometrial cancer cell lines. Journal of Clinical Endocrinology and Metabolism 77 1458-1464.

Emons G, Ortmann O, Teichert HM, Fassl H, Lohrs U, Kullander S, Kauppila A, Ayalon D, Schally A \& Oberheuser F 1996 Luteinizing hormone-releasing hormone agonist triptorelin in combination with cytotoxic chemotherapy in patients with advanced ovarian carcinoma. A prospective double blind randomized trial. Decapeptyl Ovarian Cancer Study Group. Cancer 78 1452-1460.

Emons G, Weiss S, Ortmann O, Grundker C \& Schulz KD 2000 LHRH might act as a negative autocrine regulator of proliferation of human ovarian cancer. European Journal of Endocrinology 142 665-670.

Emons G, Grundker C, Gunthert AR, Westphalen S, Kavanagh J \& Verschraegen C 2003 GnRH antagonists in the treatment of gynecological and breast cancers. Endocrine-Related Cancer 10 291-299.

Faure N, Labrie F, Lemay A, Belanger A, Gourdeau Y, Laroche B \& Robert G 1982 Inhibition of serum androgen levels by chronic intranasal and subcutaneous administration of a potent luteinizing hormone-releasing hormone (LH-RH) agonist in adult men. Fertility and Sterility 37 416-424.

Fortune JE, Sirois J, Turzillo AM \& Lavoir M 1991 Follicle selection in domestic ruminants. Journal of Reproduction and Fertility 43 (Suppl) 187-198.

Frankel AE, Kreitman RJ \& Sausville EA 2000 Targeted toxins. Clinical Cancer Research 6 326-334.

Friess H, Buchler M, Kiesel L, Kruger M \& Beger HG 1991 LH$\mathrm{RH}$ receptors in the human pancreas. Basis for antihormonal treatment in ductal carcinoma of the pancreas. International Journal of Pancreatology 10 151-159.

Gault PM, Maudsley S \& Lincoln GA 2003 Evidence that gonadotropin-releasing hormone II is not a physiological regulator of gonadotropin secretion in mammals. Journal of Neuroendocrinology 15 831-839.

Goldenberg SL, Gleave ME, Taylor D \& Bruchovsky N 1999 Clinical experience with intermittent androgen suppression in prostate cancer: minimum of 3 years' follow-up. Molecular Urology 3 287-292. 
Granger A, Ngo-Muller V, Bleux C, Guigon C, Pincas H, Magre S, Daegelen D, Tixier-Vidal A, Counis R \& Laverriere JN 2004 The promoter of the rat gonadotropin-releasing hormone receptor gene directs the expression of the human placental alkaline phosphatase reporter gene in gonadotrope cells in the anterior pituitary gland as well as in multiple extrapituitary tissues. Endocrinology 145 983-993.

van Groeninghen JC, Kiesel L, Winkler D \& Zwirner M 1998 Effects of luteinising-hormone-releasing hormone on nervoussystem tumours. Lancet 352 372-373.

Grundker C, Volker P, Schulz KD \& Emons G $2000 a$ Luteinizing hormone-releasing hormone agonist triptorelin and antagonist cetrorelix inhibit EGF-induced c-fos expression in human gynecological cancers. Gynecologic Oncology 78 194-202.

Grundker C, Schulz K, Gunthert AR \& Emons G $2000 b$ Luteinizing hormone-releasing hormone induces nuclear factor kappaB-activation and inhibits apoptosis in ovarian cancer cells. Journal of Clinical Endocrinology and Metabolism 85 3815-3820.

Grundker C, Volker P \& Emons G 2001 Antiproliferative signaling of luteinizing hormone-releasing hormone in human endometrial and ovarian cancer cells through $G$ protein alpha(I)-mediated activation of phosphotyrosine phosphatase. Endocrinology 142 2369-2380.

Grundker C, Gunthert AR, Millar RP \& Emons G $2002 a$ Expression of gonadotropin-releasing hormone II (GnRH-II) receptor in human endometrial and ovarian cancer cells and effects of GnRH-II on tumor cell proliferation. Journal of Clinical Endocrinology and Metabolism 87 1427-1430.

Grundker C, Gunthert AR, Westphalen S \& Emons G $2002 b$ Biology of the gonadotropin-releasing hormone system in gynecological cancers. European Journal of Endocrinology 146 $1-14$.

Guillemin R 1967 The adenohypophysis and its hypothalamic control. Annual Review of Physiology 29 313-348.

Gunther R, Chelstrom LM, Finnegan D, Tuel-Ahlgren L, Irvin JD, Myers DE \& Uckun FM 1993 In vivo anti-leukemic efficacy of anti-CD7-pokeweed antiviral protein immunotoxin against human T-lineage acute lymphoblastic leukemia/ lymphoma in mice with severe combined immunodeficiency. Leukemia 7 298-309.

de Haes H, Olschewski M, Kaufmann M, Schumacher M, Jonat W \& Sauerbrei W 2003 Quality of life in goserelin-treated versus cyclophosphamide + methotrexate + fluorouraciltreated premenopausal and perimenopausal patients with node-positive, early breast cancer: the Zoladex Early Breast Cancer Research Association Trialists Group. Journal of Clinical Oncology 21 4510-4516.

Halmos G, Arencibia JM, Schally AV, Davis R \& Bostwick DG 2000 High incidence of receptors for luteinizing hormonereleasing hormone (LHRH) and LHRH receptor gene expression in human prostate cancers. Journal of Urology 163 623-629.

Higano CS 2003 Side effects of androgen deprivation therapy: monitoring and minimizing toxicity. Urology $6132-38$.

Hoffken K 1992 LH-RH agonists in the treatment of premenopausal patients with advanced breast cancer. Recent Results in Cancer Research 124 91-104.
Huirne JA \& Lambalk CB 2001 Gonadotropin-releasinghormone-receptor antagonists. Lancet 358 1793-1803.

Imai A \& Tamaya T $2000 \mathrm{GnRH}$ receptor and apoptotic signaling. Vitamins and Hormones 59 1-33.

Imai A, Ohno T, Iida K, Fuseya T, Furui T \& Tamaya T 1994 Gonadotropin-releasing hormone receptor in gynecologic tumors. Frequent expression in adenocarcinoma histologic types. Cancer $\mathbf{7 4}$ 2555-2561.

Jacobs E, Watson SA, Michaeli D, Ellis IO \& Robertson JF 1999 Anti-gonadotrophin releasing hormone antibodies inhibit the growth of MCF7 human breast cancer xenografts. British Journal of Cancer 80 352-359.

Johnson L \& Thompson DL Jr 1983 Age-related and seasonal variation in the Sertoli cell population, daily sperm production and serum concentrations of follicle-stimulating hormone, luteinizing hormone and testosterone in stallions. Biology of Reproduction 29 777-789.

Jonat W, Kaufmann M, Sauerbrei W, Blamey R, Cuzick J, Namer M, Fogelman I, de Haes JC, de Matteis A, Stewart A et al. 2002 Goserelin versus cyclophosphamide, methotrexate, and fluorouracil as adjuvant therapy in premenopausal patients with node-positive breast cancer: The Zoladex Early Breast Cancer Research Association Study. Journal of Clinical Oncology 20 4628-4635.

Kakar SS \& Jennes L 1995 Expression of gonadotropin-releasing hormone and gonadotropin-releasing hormone receptor mRNAs in various non-reproductive human tissues. Cancer Letters 98 57-62.

Kakar SS, Grizzle WE \& Neill JD 1994 The nucleotide sequences of human GnRH receptors in breast and ovarian tumors are identical with that found in pituitary. Molecular and Cellular Endocrinology 106 145-149.

Kang SK, Cheng KW, Ngan ES, Chow BK, Choi KC \& Leung PC 2000 Differential expression of human gonadotropinreleasing hormone receptor gene in pituitary and ovarian cells. Molecular and Cellular Endocrinology 162 157-166.

Kang SK, Choi KC, Yang HS \& Leung PC 2003 Potential role of gonadotrophin-releasing hormone (GnRH)-I and GnRH-II in the ovary and ovarian cancer. Endocrine-Related Cancer 10 169-177.

Karten MJ \& Rivier JE 1986 Gonadotropin-releasing hormone analog design. Structure-function studies toward the development of agonists and antagonists: rationale and perspective. Endocrine Reviews 7 44-66.

Keeney DS, Sprando RL, Robaire B, Zirkin BR \& Ewing LL 1990 Reversal of long-term LH deprivation on testosterone secretion and Leydig cell volume, number and proliferation in adult rats. Journal of Endocrinology 127 47-58.

Kottler ML, Starzec A, Carre MC, Lagarde JP, Martin A \& Counis R 1997 The genes for gonadotropin-releasing hormone and its receptor are expressed in human breast with fibrocystic disease and cancer. International Journal of Cancer 71 595-599.

Kovacs M, Schally AV, Nagy A, Koppan M \& Groot K 1997 Recovery of pituitary function after treatment with a targeted cytotoxic analog of luteinizing hormone-releasing hormone. PNAS 94 1420-1425. 
Kraus S, Naor Z \& Seger R 2001 Intracellular signaling pathways mediated by the gonadotropin-releasing hormone ( $\mathrm{GnRH})$ receptor. Archives of Medical Research 32 499-509.

Krsmanovic LZ, Mores N, Navarro CE, Arora KK \& Catt KJ 2003 An agonist-induced switch in $G$ protein coupling of the gonadotropin-releasing hormone receptor regulates pulsatile neuropeptide secretion. PNAS 100 2969-2974.

Kuhn JM, Billebaud T, Navratil H, Moulonguet A, Fiet J, Grise P, Louis JF, Costa P, Husson JM, Dahan R et al. 1989 Prevention of the transient adverse effects of a gonadotropinreleasing hormone analogue (buserelin) in metastatic prostatic carcinoma by administration of an antiandrogen (nilutamide). New England Journal of Medicine 321 413-418.

Labrie F 1991 Endocrine therapy for prostate cancer. Endocrinology and Metabolism Clinics of North America $\mathbf{2 0}$ 845-872.

Labrie F 2004 Medical castration with LHRH agonists: 25 years later with major benefits achieved on survival in prostate cancer. Journal of Andrology 25 305-313.

Labrie F, Belanger A, Cusan L, Seguin C, Pelletier G, Kelly PA, Reeves JJ, Lefebure FA, Lemay A \& Ranaud JP 1980 Antifertility effects of LHRH agonists in the male. Journal of Andrology 1 209-228.

Labrie F, Belanger A, Kelly PA, Seguin C, Cusan L, Lefebvre FA, Reeves JJ, Lemay A, Faure N, Gourdeau Y et al. 1981 Antifertility effects of luteinizing hormone-releasing hormone (LHRH) agonists. Progress in Clinical and Biological Research 74 273-291.

Labrie F, Dupont A, Belanger A, Emond J \& Monfette G 1984 Simultaneous administration of pure antiandrogens, a combination necessary for the use of luteinizing hormonereleasing hormone agonists in the treatment of prostate cancer. PNAS 81 3861-3863.

Labrie F, Dupont A, Belanger A \& Lachance R 1987 Flutamide eliminates the risk of disease flare in prostatic cancer patients treated with a luteinizing hormone-releasing hormone agonist. Journal of Urology 138 804-806.

Labrie F, Belanger A, Dupont A, Luu-The V, Simard J \& Labrie C 1993 Science behind total androgen blockade: from gene to combination therapy. Clinical and Investigative Medicine $\mathbf{1 6}$ 475-492.

Labrie F, Belanger A, Cusan L, Simard J, Luu-The V, Labrie C, Gomez JL, Diamond P \& Candas B 1996 History of LHRH agonist and combination therapy in prostate cancer. Endocrine-Related Cancer 3 243-278.

Labrie F, Candas B, Gomez JL \& Cusan L 2002 Can combined androgen blockade provide long-term control or possible cure of localized prostate cancer? Urology 60 115-119.

Lee CY, Ho J, Chow SN, Yasojima K, Schwab C \& McGeer PL 2000 Immunoidentification of gonadotropin releasing hormone receptor in human sperm, pituitary and cancer cells. American Journal of Reproductive Immunology 44 170-177.

Letsch M, Schally AV, Szepeshazi K, Halmos G \& Nagy A 2003 Preclinical evaluation of targeted cytotoxic luteinizing hormone-releasing hormone analogue $\mathrm{AN}-152$ in androgensensitive and insensitive prostate cancers. Clinical Cancer Research 9 4505-4513.

Limonta P, Moretti RM, Marelli MM \& Motta M 2003 The biology of gonadotropin hormone-releasing hormone: role in the control of tumor growth and progression in humans. Frontiers in Neuroendocrinology 24 279-295.

Liu F, Usui I, Evans LG, Austin DA, Mellon PL, Olefsky JM \& Webster NJ 2002 Involvement of both G(q/11) and G(s) proteins in gonadotropin-releasing hormone receptormediated signaling in L beta T2 cells. Journal of Biological Chemistry 277 32099-32108.

Liu F, Austin DA \& Webster NJ 2003 Gonadotropin-releasing hormone-desensitized LbetaT2 gonadotrope cells are refractory to acute protein kinase C, cyclic AMP, and calcium-dependent signaling. Endocrinology 144 4354-4365.

Loblaw DA, Mendelson DS, Talcott JA, Virgo KS, Somerfield MR, Ben-Josef E, Middleton R, Porterfield H, Sharp SA, Smith TJ et al. 2004 American Society of Clinical Oncology recommendations for the initial hormonal management of androgen-sensitive metastatic, recurrent, or progressive prostate cancer. Journal of Clinical Oncology 22 2927-2941.

van Loenen AC, Huirne JA, Schats R, Hompes PG \& Lambalk CB 2002 GnRH agonists, antagonists, and assisted conception. Seminars in Reproductive Medicine 20 349-364.

Love RR \& Philips J 2002 Oophorectomy for breast cancer: history revisited. Journal of the National Cancer Institute $\mathbf{9 4}$ 1433-1434.

McArdle CA, Franklin J, Green L \& Hislop JN 2002 Signalling, cycling and desensitisation of gonadotrophin-releasing hormone receptors. Journal of Endocrinology 173 1-11.

MacColl G, Quinton R \& Bouloux PM 2002 GnRH neuronal development: insights into hypogonadotrophic hypogonadism. Trends in Endocrinology and Metabolism $\mathbf{1 3}$ 112-118.

McCue JM, Quirk CC, Nelson SE, Bowen RA \& Clay CM 1997 Expression of a murine gonadotropin-releasing hormone receptor-luciferase fusion gene in transgenic mice is diminished by immunoneutralization of gonadotropinreleasing hormone. Endocrinology 138 3154-3160.

Marcil J, Ravindranath N \& Sairam MR 1993 Cytotoxic activity of lutropin-gelonin conjugate in mouse Leydig tumor cells: potentiation of the hormonotoxin activity by different drugs. Molecular and Cellular Endocrinology 92 83-90.

Messing EM, Manola J, Sarosdy M, Wilding G, Crawford ED \& Trump D 1999 Immediate hormonal therapy compared with observation after radical prostatectomy and pelvic lymphadenectomy in men with node-positive prostate cancer. New England Journal of Medicine 341 1781-1788.

Miles LE, Hanyaloglu AC, Dromey JR, Pfleger KD \& Eidne KA 2004 Gonadotropin-releasing hormone receptor-mediated growth suppression of immortalized LbetaT2 gonadotrope and stable HEK293 cell lines. Endocrinology 145 194-204.

Miller WR, Scott WN, Morris R, Fraser HM \& Sharpe RM 1985 Growth of human breast cancer cells inhibited by a luteinizing hormone-releasing hormone agonist. Nature 313 231-233.

Millikan R \& Logothetics C 1997 National Comprehensive Cancer Network (NCC) Practice Guidelines version 1.97. Oncology 11 180-201.

Myers DA \& Villemez CL 1989 A superactive hormonotoxin prepared with truncated diphtheria toxin. Biochemical and Biophysical Research Communications 163 161-164.

Nechushtan A, Yarkoni S, Marianovsky I \& Lorberboum-Galski H 1997 Adenocarcinoma cells are targeted by the new GnRH- 
PE66 chimeric toxin through specific gonadotropin-releasing hormone binding sites. Journal of Biological Chemistry $\mathbf{2 7 2}$ 11597-11603.

Neill JD 2002 GnRH and GnRH receptor genes in the human genome. Endocrinology 143 737-743.

Nichols J, Foss F, Kuzel TM, LeMaistre CF, Platanias L, Ratain MJ, Rook A, Saleh M \& Schwartz G 1997 Interleukin-2 fusion protein: an investigational therapy for interleukin-2 receptor expressing malignancies. European Journal of Cancer 33 (Suppl 1) S34-S36.

Nicholson RI \& Walker KJ 1989 Gn-RH agonists in breast and gynaecologic cancer treatment. Journal of Steroid Biochemistry 33 801-804.

Noci I, Coronnello M, Borri P, Borrani E, Giachi M, Chieffi O, Marchionni M, Paglierani M, Buccoliero AM, Cherubini A et al. 2000 Inhibitory effect of luteinising hormone-releasing hormone analogues on human endometrial cancer in vitro. Cancer Letters 150 71-78.

Norwitz ER, Xu S, Jeong KH, Bedecarrats GY, Winebrenner LD, Chin WW \& Kaiser UB $2002 a$ Activin A augments GnRH-mediated transcriptional activation of the mouse GnRH receptor gene. Endocrinology 143 985-997.

Norwitz ER, Xu S, Xu J, Spiryda LB, Park JS, Jeong KH, McGee EA \& Kaiser UB $2002 b$ Direct binding of AP-1 (Fos/ Jun) proteins to a SMAD binding element facilitates both gonadotropin-releasing hormone $(\mathrm{GnRH})$ - and activinmediated transcriptional activation of the mouse GnRH receptor gene. Journal of Biological Chemistry 277 3746937478 .

Oefelein MG \& Resnick MI 2003 Effective testosterone suppression for patients with prostate cancer: is there a best castration? Urology 62 207-213.

Oefelein MG, Ricchiuti VS, Conrad PW, Goldman H, Bodner D, Resnick MI \& Seftel A 2002 Clinical predictors of androgenindependent prostate cancer and survival in the prostatespecific antigen era. Urology 60 120-124.

Olsen E, Duvic M, Frankel A, Kim Y, Martin A, Vonderheid E, Jegasothy B, Wood G, Gordon M, Heald P et al. 2001 Pivotal phase III trial of two dose levels of denileukin diftitox for the treatment of cutaneous T-cell lymphoma. Journal of Clinical Oncology 19 376-388.

Ortmann O \& Diedrich K 1999 Pituitary and extrapituitary actions of gonadotrophin-releasing hormone and its analogues. Human Reproduction 14 (Suppl 1) 194-206.

Pai LH, Batra JK, FitzGerald DJ, Willingham MC \& Pastan I 1992 Antitumor effects of B3-PE and B3-LysPE40 in a nude mouse model of human breast cancer and the evaluation of B3-PE toxicity in monkeys. Cancer Research 52 3189-3193.

Pater JL \& Parulekar WR 2003 Ovarian ablation as adjuvant therapy for premenopausal women with breast cancer another step forward. Journal of the National Cancer Institute $951811-1812$.

Pawson AJ, Morgan K, Maudsley SR \& Millar RP 2003 Type II gonadotrophin-releasing hormone (GnRH-II) in reproductive biology. Reproduction 126 271-278.

Pether M, Goldenberg SL, Bhagirath K \& Gleave M 2003 Intermittent androgen suppression in prostate cancer: an update of the Vancouver experience. Canadian Journal of Urology 10 1809-1814.
Pilepich MV, Krall JM, al-Sarraf M, John MJ, Doggett RL, Sause WT, Lawton CA, Abrams RA, Rotman M, Rubin P et al. 1995 Androgen deprivation with radiation therapy compared with radiation therapy alone for locally advanced prostatic carcinoma: a randomized comparative trial of the Radiation Therapy Oncology Group. Urology 45 616-623.

Pitteloud N, Hayes FJ, Dwyer A, Boepple PA, Lee H \& Crowley WF Jr 2002 Predictors of outcome of long-term GnRH therapy in men with idiopathic hypogonadotropic hypogonadism. Journal of Clinical Endocrinology and Metabolism 87 4128-4136.

Pound CR, Partin AW, Eisenberger MA, Chan DW, Pearson JD \& Walsh PC 1999 Natural history of progression after PSA elevation following radical prostatectomy. Journal of the American Medical Association 281 1591-1597.

Pritchard KI 2000 Current and future directions in medical therapy for breast carcinoma: endocrine treatment. Cancer $\mathbf{8 8}$ 3065-3072.

Pritchard KI 2002 Adjuvant therapy for premenopausal women with breast cancer: is it time for another paradigm shift? Journal of Clinical Oncology 20 4611-4614.

Qi L, Nett TM, Allen MC, Sha X, Harrison GS, Frederick BA \& Glode LM 2003 GnRH-PAP hormonotoxin targets cytotoxicity to prostate cancer cell lines. Urology Research $\mathbf{3 1}$ 374-377.

Qi L, Nett TM, Allen MC, Sha X, Harrison GS, Frederick BA, Crawford ED \& Glode LM 2004 Binding and cytotoxicity of conjugated and recombinant fusion proteins targeted to the gonadotropin-releasing hormone receptor. Cancer Research 64 2090-2095.

Quella SK, Loprinzi CL, Sloan J, Novotny P, Perez EA, Burch PA, Antolak SJ Jr \& Pisansky TM 1999 Pilot evaluation of venlafaxine for the treatment of hot flashes in men undergoing androgen ablation therapy for prostate cancer. Journal of Urology 162 98-102.

Roelle S, Grosse R, Aigner A, Krell HW, Czubayko F \& Gudermann T 2003 Matrix metalloproteinases 2 and 9 mediate epidermal growth factor receptor transactivation by gonadotropin-releasing hormone. Journal of Biological Chemistry 278 47307-47318.

Ruf F, Fink MY \& Sealfon SC 2003 Structure of the GnRH receptor-stimulated signaling network: insights from genomics. Frontiers in Neuroendocrinology 24 181-199.

Sabbatini P, Larson SM, Kremer A, Zhang ZF, Sun M, Yeung H, Imbriaco M, Horak I, Conolly M, Ding C et al. 1999 Prognostic significance of extent of disease in bone in patients with androgen-independent prostate cancer. Journal of Clinical Oncology 17 948-957.

Sabeur K, Ball BA, Nett TM, Ball HH \& Liu IK 2003 Effect of $\mathrm{GnRH}$ conjugated to pokeweed antiviral protein on reproductive function in adult male dogs. Reproduction $\mathbf{1 2 5}$ 801-806.

Sadie H, Styger G \& Hapgood J 2003 Expression of the mouse gonadotropin-releasing hormone receptor gene in alpha T3-1 gonadotrope cells is stimulated by cyclic $3^{\prime}, 5^{\prime}$-adenosine monophosphate and protein kinase A, and is modulated by Steroidogenic factor-1 and Nur77. Endocrinology 144 1958-1971. 
Samdal F, Vada K, Lundmo PI \& Mjolnerod OK 1991 Orchidectomy or LHRH-analogue? Which do the patients prefer and what treatment would Norwegian urologists prefer if they had advanced cancer of the prostate? Scandinavian Journal of Urology and Nephrology 25 197-199.

Sato N, Gleave ME, Bruchovsky N, Rennie PS, Goldenberg SL, Lange PH \& Sullivan LD 1996 Intermittent androgen suppression delays progression to androgen-independent regulation of prostate-specific antigen gene in the $\mathrm{LNCaP}$ prostate tumour model. Journal of Steroid Biochemistry and Molecular Biology 58 139-146.

Schlick J, Dulieu P, Desvoyes B, Adami P, Radom J \& Jouvenot M 2000 Cytotoxic activity of a recombinant GnRH-PAP fusion toxin on human tumor cell lines. FEBS Letters $\mathbf{4 7 2}$ 241-246.

Schwartz J \& Vale W 1988 Dissociation of the adrenocorticotropin secretory responses to corticotropinreleasing factor (CRF) and vasopressin or oxytocin by using a specific cytotoxic analog of CRF. Endocrinology 122 1695-1700.

Schwartz J, Penke B, Rivier J \& Vale W 1987 A new cytotoxin specific for the target cells of corticotropin-releasing factor. Endocrinology 121 1454-1460.

Shah BH, Farshori MP, Jambusaria A \& Catt KJ 2003 Roles of Src and epidermal growth factor receptor transactivation in transient and sustained ERK1/2 responses to gonadotropinreleasing hormone receptor activation. Journal of Biological Chemistry 278 19118-19126.

Simms MS, Scholfield DP, Jacobs E, Michaeli D, Broome P, Humphreys JE \& Bishop MC 2000 Anti-GnRH antibodies can induce castrate levels of testosterone in patients with advanced prostate cancer. British Journal of Cancer $\mathbf{8 3}$ 443-446.

Singh V \& Curtiss R 3rd 1991 Hormonotoxins: abrogation of ribosome inactivating property of gelonin in the disulfide linked ovine luteinizing hormone-gelonin conjugates. Biochemistry International 25 531-536.

Singh V \& Curtiss R 3rd 1994 Hormonotoxins: the role of positive charge of lysine residue on the immunological, biological and cytotoxic properties of ovine lutropin-S-Sgelonin conjugates. Molecular and Cellular Biochemistry 130 91-101.

Smith MR 2003 Diagnosis and management of treatment-related osteoporosis in men with prostate carcinoma. Cancer 97 789-795.

Straub B, Muller M, Krause H, Schrader M, Goessl C, Heicappell R \& Miller K 2001 Increased incidence of luteinizing hormone-releasing hormone receptor gene messenger RNA expression in hormone-refractory human prostate cancers. Clinical Cancer Research 7 2340-2343.

Sunderland MC \& Osborne CK 1991 Tamoxifen in premenopausal patients with metastatic breast cancer: a review. Journal of Clinical Oncology 9 1283-1297.

Szoke B, Horvath J, Halmos G, Rekasi Z, Groot K, Nagy A \& Schally AV 1994 LH-RH analogue carrying a cytotoxic radical is internalized by rat pituitary cells in vitro. Peptides $\mathbf{1 5}$ 359-366.

Taylor CW, Green S, Dalton WS, Martino S, Rector D, Ingle JN, Robert NJ, Budd GT, Paradelo JC, Natale RB et al. 1998
Multicenter randomized clinical trial of goserelin versus surgical ovariectomy in premenopausal patients with receptor-positive metastatic breast cancer: an intergroup study. Journal of Clinical Oncology 16 994-999.

Terasawa E 2003 Gonadotropin-releasing hormone II: is this neuropeptide important for mammalian reproduction? Endocrinology 144 3-4.

Terasawa E \& Fernandez DL 2001 Neurobiological mechanisms of the onset of puberty in primates. Endocrine Reviews $\mathbf{2 2}$ 111-151.

Thrush GR, Lark LR, Clinchy BC \& Vitetta ES 1996 Immunotoxins: an update. Annual Review of Immunology 14 49-71.

Tobet SA, Bless EP \& Schwarting GA 2001 Developmental aspect of the gonadotropin-releasing hormone system. Molecular and Cellular Endocrinology 185 173-184.

Trachtenberg J, Gittleman M, Steidle C, Barzell W, Friedel W, Pessis D, Fotheringham N, Campion M \& Garnick MB 2002 A phase 3, multicenter, open label, randomized study of abarelix versus leuprolide plus daily antiandrogen in men with prostate cancer. Journal of Urology 167 1670-1674.

Uckun FM, Bellomy K, O’Neill K, Messinger Y, Johnson T \& Chen CL 1999 Toxicity, biological activity, and pharmacokinetics of TXU (anti-CD7)-pokeweed antiviral protein in chimpanzees and adult patients infected with human immunodeficiency virus. Journal of Pharmacology and Experimental Therapeutics 291 1301-1307.

Vasilyev VV, Lawson MA, Dipaolo D, Webster NJ \& Mellon PL 2002 Different signaling pathways control acute induction versus long-term repression of LHbeta transcription by GnRH. Endocrinology 143 3414-3426.

Vickery BH 1986 Comparison of the potential for therapeutic utilities with gonadotropin-releasing hormone agonists and antagonists. Endocrine Reviews 7 115-124.

Virgolini I, Traub T, Novotny C, Leimer M, Fuger B, Li SR, Patri P, Pangerl T, Angelberger P, Raderer M et al. 2002 Experience with indium-111 and yttrium-90-labeled somatostatin analogs. Current Pharmaceutical Design 8 17811807.

de Voogt HJ, Suciu S, Sylvester R, Pavone-Macaluso M, Smith PH \& de Pauw M 1989 Multivariate analysis of prognostic factors in patients with advanced prostatic cancer: results from 2 European Organization for Research on Treatment of Cancer trials. Journal of Urology 141 883-888.

Wang Y, Matsuo H, Kurachi O \& Maruo T 2002 Downregulation of proliferation and up-regulation of apoptosis by gonadotropin-releasing hormone agonist in cultured uterine leiomyoma cells. European Journal of Endocrinology 146 447-456.

Warner B, Worgul TJ, Drago J, Demers L, Dufau M, Max D \& Santen RJ 1983 Effect of very high dose D-leucine6gonadotropin-releasing hormone proethylamide on the hypothalamic-pituitary testicular axis in patients with prostatic cancer. Journal of Clinical Investigation $\mathbf{7 1}$ 1842-1853.

Weinbauer GF \& Nieschlag E 1992 LH-RH antagonists: state of the art and future perspectives. Recent Results in Cancer Research 124 113-136. 
Wierman ME 1996 Gonadotropin-releasing hormone. In Reproductive Endocrinology, Surgery, and Technology, pp 666-681. Eds EY Adashi, JA Rock \& Z Rosewaks. Philadelphia: Lippincott-Raven Publishers.

Wierman ME, Pawlowski JE, Allen MP, Xu M, Linseman DA \& Nielsen-Preiss S 2004 Molecular mechanisms of gonadotropin-releasing hormone neuronal migration. Trends in Endocrinology and Metabolism 15 96-102.

Xu C, Xu XZ, Nunemaker CS \& Moenter SM 2004 Dosedependent switch in response of gonadotropin-releasing hormone (GnRH) neurons to GnRH mediated through the type I GnRH receptor. Endocrinology 145 728-735.

Yang WH, Wieczorck M, Allen MC \& Nett TM 2003 Cytotoxic activity of gonadotropin-releasing hormone (GnRH)pokeweed antiviral protein conjugates in cell lines expressing GnRH receptors. Endocrinology 144 1456-1463.

Yin H, Cheng KW, Hwa HL, Peng C, Auersperg N \& Leung PC 1998 Expression of the messenger RNA for gonadotropinreleasing hormone and its receptor in human cancer cell lines. Life Sciences 62 2015-2023. 